Clim. Past, 9, 2153-2171, 2013

www.clim-past.net/9/2153/2013/

doi:10.5194/cp-9-2153-2013

(C) Author(s) 2013. CC Attribution 3.0 License.

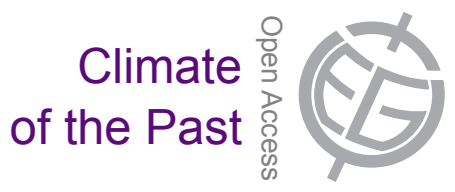

\title{
Mid-Holocene ocean and vegetation feedbacks over East Asia
}

\author{
Z. Tian $^{1,2}$ and D. Jiang ${ }^{1,3,4}$ \\ ${ }^{1}$ Nansen-Zhu International Research Centre, Institute of Atmospheric Physics, Chinese Academy of Sciences, Beijing, China \\ ${ }^{2}$ University of Chinese Academy of Sciences, Beijing, China \\ ${ }^{3}$ Key Laboratory of Regional Climate-Environment Research for Temperate East Asia, Chinese Academy of Sciences, \\ Beijing, China \\ ${ }^{4}$ Climate Change Research Center, Chinese Academy of Sciences, Beijing, China \\ Correspondence to: Z. Tian (tianzhiping@mail.iap.ac.cn)
}

Received: 6 November 2012 - Published in Clim. Past Discuss.: 4 January 2013

Revised: 6 July 2013 - Accepted: 22 July 2013 - Published: 13 September 2013

\begin{abstract}
Mid-Holocene ocean and vegetation feedbacks over East Asia are investigated by a set of numerical experiments performed with the version 4 of the Community Climate System Model (CCSM4). With reference to the pre-industrial period, most of the mid-Holocene annual and seasonal surface-air temperature and precipitation changes are found to result from a direct response of the atmosphere to insolation forcing, while dynamic ocean and vegetation modulate regional climate of East Asia to some extent. Because of its thermal inertia, the dynamic ocean induced an additional warming of $0.2 \mathrm{~K}$ for the annual mean, $0.5 \mathrm{~K}$ in winter (December-February), $0.0003 \mathrm{~K}$ in summer (June-August), and $1.0 \mathrm{~K}$ in autumn (SeptemberNovember), but a cooling of $0.6 \mathrm{~K}$ in spring (March-May) averaged over China, and it counteracted (amplified) the direct effect of insolation forcing for the annual mean and in winter and autumn (spring) for that period. The dynamic vegetation had an area-average impact of no more than $0.4 \mathrm{~K}$ on the mid-Holocene annual and seasonal temperatures over China, with an average cooling of $0.2 \mathrm{~K}$ for the annual mean. On the other hand, ocean feedback induced a small increase of precipitation in winter $\left(0.04 \mathrm{~mm} \mathrm{day}^{-1}\right)$ and autumn $\left(0.05 \mathrm{~mm} \mathrm{day}^{-1}\right)$, but a reduction for the annual mean $\left(0.14 \mathrm{~mm} \mathrm{day}^{-1}\right)$ and in spring $\left(0.29 \mathrm{~mm} \mathrm{day}^{-1}\right)$ and summer $\left(0.34 \mathrm{~mm} \mathrm{day}^{-1}\right)$ over China, while it also suppressed the East Asian summer monsoon rainfall. The effect of dynamic vegetation on the mid-Holocene annual and seasonal precipitation was comparatively small, ranging from $-0.03 \mathrm{~mm} \mathrm{day}^{-1}$ to $0.06 \mathrm{~mm} \mathrm{day}^{-1}$ averaged over China. In comparison, the CCSM4 simulated annual and winter cooling over China agrees with simulations within the
\end{abstract}

Paleoclimate Modeling Intercomparison Project (PMIP), but the results are contrary to the warming reconstructed from multiple proxy data for the mid-Holocene. Ocean feedback narrows this model-data mismatch, whereas vegetation feedback plays an opposite role but with a level of uncertainty.

\section{Introduction}

Paleoclimate modeling is one of the most important aspects in past climate change research. Combining model results with proxy data provides a unique opportunity to investigate the cause and effect of natural variability of past climate over a wide range of timescales, which is of significance when trying to better understand the present climate as well as predict and project future climate changes.

The mid-Holocene is a period that occurred approximately $6000 \mathrm{yr}$ before present, when the climate and environment were significantly different from today (e.g., Prentice and Webb, 1998; Bartlein et al., 2011) mainly due to a change in incoming solar radiation at the top of the atmosphere (Berger, 1978). It is an ideal time period for studying past climate change on the orbital scale, during which time proxy records are abundant and relatively reliable. The mid-Holocene is also one of the benchmark periods under the protocol of the Paleoclimate Modeling Intercomparison Project (PMIP), with its initial stage (PMIP1) designed to test the atmospheric component of climate models (atmospheric general circulation models, AGCMs) and its second and third stages (PMIP2 and PMIP3) having incorporated the roles of the dynamic ocean (atmosphere-ocean general 
circulation models, AOGCMs) and vegetation (atmosphereocean-vegetation general circulation models, AOVGCMs). The impact of changes in the orbital parameters on the midHolocene climate has been extensively simulated with a hierarchy of climate models. It is shown that, although insolation changes were the primary cause of mid-Holocene climate change, interactive ocean and vegetation, as well as their synergy effects, might also have considerably modified the annual and seasonal climate response to insolation forcing (Braconnot et al., 2000, 2007; Liu et al., 2004; Wohlfahrt et al., 2004; Otto et al., 2009a, b; O'ishi and Abe-Ouchi, 2011; Zhao and Harrison, 2012). However, there is no consensus on the relative effect of ocean and vegetation feedbacks, the strength of the synergy between them, and their regional expression. Besides, previous studies have focused mainly on the mid-Holocene climate change either at the global scale (e.g., Wohlfahrt et al., 2004; Braconnot et al., 2007; Otto et al., 2009a, b; O'ishi and Abe-Ouchi, 2011) or over the monsoon regions of northern or southern Africa (e.g., Joussaume et al., 1999; Braconnot et al., 2000; Liu et al., 2004; Zhao and Harrison, 2012), North or South America, or northern Australia (e.g., Liu et al., 2004; Zhao and Harrison, 2012), whereas fewer attentions have been given to the East Asian monsoon regions. Thus, more comprehensive simulations of the mid-Holocene climate change over East Asia appear to be necessary.

Much effort has been devoted to reconstructing the midHolocene climate over East Asia using a variety of proxy data, suggesting that China experienced warmer and wetter than present climate conditions as a whole during that time (see Sect. 5). By contrast, only a few simulations of the mid-Holocene East Asian climate have been performed using AGCMs (Wang, 1999, 2000, 2002; Chen et al., 2002; Wang and Wang, 2013), regional climate models nested within AGCMs (Zheng et al., 2004; Liu et al., 2010), synchronously or asynchronously coupled AOGCMs (Wei and Wang, 2004; Zheng and Yu, 2009), and AOVGCM (Dallmeyer et al., 2010). In those earlier studies, warmer-than-present climate and intensified monsoon circulation over East Asia during the mid-Holocene summer (June-August) have been reasonably reproduced, but the geographical distribution and magnitude of summer climate change have varied among simulations, indicative of a large degree of uncertainty. Furthermore, little attention has been paid to climate change for the annual mean and the other three seasons. Therefore, it is of interest to examine what East Asian climate was like during the mid-Holocene in simulations with state-of-the-art climate models.

Second, many numerical experiments indicate that ocean feedback played an important role in the mid-Holocene climate change, particularly in amplifying orbitally induced changes in the northern African monsoon (e.g., Kutzbach and Liu, 1997; Hewitt and Mitchell, 1998; Braconnot et al., 2000; Voss and Mikolajewicz, 2001; Liu et al., 2004). However, it remains uncertain on the role of the dynamic ocean on the mid-Holocene Asian summer monsoon. Several simulations have shown an increase of Asian monsoon precipitation due to the ocean-atmosphere interaction (e.g., Braconnot et al., 2000; Wei and Wang, 2004; Zhao and Harrison, 2012), whereas others have suggested a suppression of Asian summer precipitation (e.g., Liu et al., 2004; Ohgaito and Abe-Ouchi, 2007; Li and Harrison, 2008; Marzin and Braconnot, 2009). Such differences in the Asian monsoon behavior inspire us to investigate the effect of ocean feedback on the East Asian monsoon climate during the mid-Holocene through specific numerical experiments.

Third, vegetation feedback has been proposed as an important process contributing to the mid-Holocene climate system (Jansen et al., 2007). Previous simulations with reconstructed paleovegetation or dynamic vegetation models indicate that the mid-Holocene changes in vegetation modify the climate system response to an enhanced seasonal cycle of insolation in the Northern Hemisphere (e.g., Kutzbach et al., 1996; Ganopolski et al., 1998; Braconnot et al., 1999; Wang, 1999; Texier et al., 2000; Diffenbaugh and Sloan, 2002; Levis et al., 2004a; Gallimore et al., 2005; Li et al., 2009; Dallmeyer et al., 2010; O'ishi and Abe-Ouchi, 2011). Over China, regional reconstructed paleovegetation is argued to have an overall warming effect on the annual temperature based on AGCM or regional climate model experiments for that period (Chen et al., 2002; Zheng et al., 2004; Liu et al., 2010). Recently, Jiang et al. (2012) found that 35 of (all) the 36 PMIP1 and PMIP2 models reproduced colder-than-baseline annual (winter, December-February) temperatures over China during the mid-Holocene, being opposite of warmer-than-present conditions as derived from multiple proxy data sources. Similar results were obtained from 10 PMIP3 model median (Zheng et al., 2013). Furthermore, Jiang et al. (2012) showed that interactive ocean induced a warming effect on annual, winter, and autumn (September-November) temperatures, while interactive vegetation had little impact on annual and seasonal temperature over China. In this respect, however, the differences between the PMIP AGCM and AOGCM (AOGCM and AOVGCM) control simulations introduced a bias into the role of ocean-atmosphere (vegetation-atmosphere) interaction on the mid-Holocene climate as discussed by Jiang et al. (2012). Therefore, another key purpose of this study is to examine pure ocean and vegetation feedbacks over East Asia during the mid-Holocene using rigorous experiments of climate models.

After a short description of the model and experimental design in Sect. 2, we discuss the simulated climate change over East Asia between the mid-Holocene and pre-industrial period (Sect. 3). The contributions of ocean and vegetation feedbacks are further examined in Sect. 4. Finally, following a model-data comparison in Sect. 5, summary and discussion are presented in Sect. 6 . 


\section{Methods}

\subsection{Model and experiments}

The National Center for Atmospheric Research (NCAR) Community Climate System Model version 4 (CCSM4) used here is a globally coupled ocean-atmosphere-sea-ice-landsurface climate model. A detailed description of the model can be found in Gent et al. (2011), and the following is a brief outline of the four model components. The atmospheric model is the NCAR Community Atmosphere Model version 4 (CAM4; Neale et al., 2010), which employs a T31 spectral dynamical core at a horizontal resolution of approximately $3.75^{\circ} \times 3.75^{\circ}$ and with 26 vertical levels. The land model, run on the same horizontal grid as the atmosphere, is the Community Land Model version 4 (CLM4; Lawrence et al., 2012). Based on the Parallel Ocean Program (POP) of the Los Alamos National Laboratory (Smith et al., 2010), the ocean model component (POP2) is described in Danabasoglu et al. (2012), which uses a $3^{\circ}$ horizontal grid with $60 \mathrm{lev}$ els in the vertical direction. The sea-ice component is based on the Community Ice Code version 4 (CICE4; Hunke and Lipscomb, 2008), and major updates of the ice model compared to CCSM3 are discussed in Holland et al. (2012). The ice model uses the same horizontal grid as the ocean model component. More details on CCSM4 are available online at http://www.cesm.ucar.edu/models/ccsm4.0/, and further information on the model improvements and specifics about the higher resolution simulations can be found in Gent et al. (2011) and Shields et al. (2012).

More specifically on dynamic vegetation, prior versions of CLM include options to run a dynamic global vegetation model (DGVM; Levis et al., 2004b) since CLM2 or a prognostic carbon-nitrogen (CN) model (Thornton et al., 2007) since CLM3.5, but these options are mutually incompatible. CLM4 now includes the option to run the CN model merged with the DGVM, namely CNDV. The new CNDV option of CLM4 has been specifically evaluated by comparing the simulated vegetation distribution with the offline experiment against the satellite observations (Gotangco Castillo et al., 2012). It shows that CNDV simulates the present-day distribution of plant functional types reasonably well, though it underestimates shrubs and grasses in tundra regions, which is a known bias due to soil moisture in the standard CLM4 CN model (Lawrence et al., 2011). Over East Asia, CCSM4, with the same horizontal resolution of T31, has been tested against observation and reanalysis data to evaluate its performance in reproducing the present-day climate, and the results showed a reliable capability in terms of large-scale climate features and atmospheric circulation (Tian et al., 2012).

The present experiments are designed to separate the contribution of ocean or vegetation feedback from total climate change between the mid-Holocene $(6 \mathrm{ka})$ and preindustrial $(0 \mathrm{ka})$ periods. Following the PMIP3 protocol, as listed in Table 1, the major difference in boundary conditions
Table 1. Boundary conditions used for $0 \mathrm{ka}$ and $6 \mathrm{ka}$ experiments.

\begin{tabular}{|c|c|c|}
\hline & $0 \mathrm{ka}$ & $6 \mathrm{ka}$ \\
\hline Solar constant $\left(\mathrm{W} \mathrm{m}^{-2}\right)$ & 1365 & 1365 \\
\hline \multicolumn{3}{|c|}{ Earth's orbital parameters (Orbit) } \\
\hline Eccentricity & 0.016724 & 0.018682 \\
\hline Obliquity $\left(^{\circ}\right)$ & 23.446 & 24.105 \\
\hline Angular precession $\left(^{\circ}\right)$ & 102.04 & 0.87 \\
\hline \multicolumn{3}{|c|}{ Atmospheric concentrations of greenhouse gases (GHGs) } \\
\hline $\mathrm{CO}_{2}(\mathrm{ppmv})$ & 284.5 & 280 \\
\hline $\mathrm{CH}_{4}(\mathrm{ppbv})$ & 791.6 & 650 \\
\hline $\mathrm{N}_{2} \mathrm{O}$ (ppbv) & 275.7 & 270 \\
\hline
\end{tabular}

between the two periods lies in the earth's orbital parameters (Berger, 1978), leading to an increase (a decrease) in the mid-Holocene seasonal cycle of incoming solar radiation at the top of the atmosphere in the Northern (Southern) Hemisphere. Additionally, the atmospheric concentrations of $\mathrm{CH}_{4}$, $\mathrm{CO}_{2}$, and $\mathrm{N}_{2} \mathrm{O}$ decreased during the mid-Holocene with respect to the pre-industrial levels.

Altogether, six experiments were undertaken (Table 2). We first performed two experiments with the fully coupled CCSM4: a pre-industrial control run with $0 \mathrm{ka}$ orbital parameters and atmospheric concentrations of greenhouse gases (GHGs; $\mathrm{AOV}(0 \mathrm{ka}))$ and a mid-Holocene simulation with $6 \mathrm{ka}$ orbital parameters and GHGs $(\mathrm{AOV}(6 \mathrm{ka}))$. To spin up the $\operatorname{AOV}(0 \mathrm{ka})$ experiment, we first ran the $\mathrm{CN}$ model to a steady state from an initial condition of no vegetation using the "accelerated decomposition spinup" mode for 651 model years. Then, we continued from the end of this simulation and ran the CNDV model for 200 more years. After that, we used the last state from the CNDV spinup as initial conditions to run the fully coupled $\operatorname{AOV}(0 \mathrm{ka})$ experiment for a further $800 \mathrm{yr}$ until the vegetation distribution reached equilibrium. Taken together, the $\operatorname{AOV}(0 \mathrm{ka})$ simulation was run for 1651 model years. In AOV(6 ka), the model was continued from the last state of $\operatorname{AOV}(0 \mathrm{ka})$ and ran for $400 \mathrm{yr}$ until the global vegetation pattern reached equilibrium. Second, we performed two AOGCM simulations without dynamic vegetation for the pre-industrial and mid-Holocene, namely $\mathrm{AO}(0 \mathrm{ka})$ and $\mathrm{AO}(6 \mathrm{ka})$, in which vegetation was prescribed at the pre-industrial equilibrium state from $\operatorname{AOV}(0 \mathrm{ka})$. These two AOGCMs were run for $800 \mathrm{yr}$ and $700 \mathrm{yr}$, until their trends in global temperature were less than $0.05^{\circ} \mathrm{C}$ per century (Braconnot et al., 2007). To isolate the contribution of ocean feedback, we performed two additional atmosphereonly experiments $(\mathrm{A}(0 \mathrm{ka})$ and $\mathrm{A}(6 \mathrm{ka}))$ with fixed vegetation from $\operatorname{AOV}(0 \mathrm{ka})$ and fixed sea surface temperatures (SSTs) from $\mathrm{AO}(0 \mathrm{ka})$. Both of the AGCM experiments were run for $30 \mathrm{yr}$. The output from the last 100 model years in the two AOVGCM and two AOGCM simulations as well as the last 
Table 2. Summary of experiments.

\begin{tabular}{lllllr}
\hline Experiment & Vegetation treatment & SST treatment & Orbit & GHGs & Integration \\
\hline $\mathrm{AOV}(0 \mathrm{ka})$ & dynamic & dynamic & $0 \mathrm{ka}$ & $0 \mathrm{ka}$ & $1651 \mathrm{yr}$ \\
$\mathrm{AOV}(6 \mathrm{ka})$ & dynamic & dynamic & $6 \mathrm{ka}$ & $6 \mathrm{ka}$ & $400 \mathrm{yr}$ \\
$\mathrm{AO}(0 \mathrm{ka})$ & fixed as AOV $(0 \mathrm{ka})$ & dynamic & $0 \mathrm{ka}$ & $0 \mathrm{ka}$ & $800 \mathrm{yr}$ \\
$\mathrm{AO}(6 \mathrm{ka})$ & fixed as AOV $(0 \mathrm{ka})$ & dynamic & $6 \mathrm{ka}$ & $6 \mathrm{ka}$ & $700 \mathrm{yr}$ \\
$\mathrm{A}(0 \mathrm{ka})$ & fixed as AOV $(0 \mathrm{ka})$ & fixed as $\mathrm{AO}(0 \mathrm{ka})$ & $0 \mathrm{ka}$ & $0 \mathrm{ka}$ & $30 \mathrm{yr}$ \\
$\mathrm{A}(6 \mathrm{ka})$ & fixed as AOV $(0 \mathrm{ka})$ & fixed as $\mathrm{AO}(0 \mathrm{ka})$ & $6 \mathrm{ka}$ & $6 \mathrm{ka}$ & $30 \mathrm{yr}$ \\
\hline
\end{tabular}

$20 \mathrm{yr}$ in the two AGCM simulations were used for analysis. Note that the orbital changes affect the length of the seasons (Joussaume and Braconnot, 1997; Timm et al., 2008). Considering that such changes were no more than five days during the mid-Holocene (Joussaume and Braconnot, 1997), the following seasonal means are calculated based on the modern calendar instead of the celestial one.

\subsection{Analysis methods}

In most of previous studies, the analysis of dynamic ocean (vegetation) feedback during the mid-Holocene is not straightforward because AGCM and AOGCM (AOGCM and AOVGCM) experiments have used different control experiments. For example, a comparison between the two sets of simulations based on PMIP1 AGCMs and PMIP2 AOGCMs did not strictly diagnose the ocean feedback, owing to the different versions of the atmospheric component (Jiang et al., 2012; Zhao and Harrison, 2012), which also introduced a bias between the SST-forced and the coupled control simulations as discussed by Marzin and Braconnot (2009). Furthermore, when investigating vegetation feedback, it is more reasonable to run the AOGCM 6 ka simulation with prescribed vegetation of the AOVGCM 0 ka simulation, as suggested by Braconnot et al. (2007), Dallmeyer et al. (2010) and O'ishi and Abe-Ouchi (2011). In the present study, the aforementioned biases are taken into account to obtain more realistic results. The AOGCM and AGCM $6 \mathrm{ka}$ simulations share the same $0 \mathrm{ka}$ simulation $(\mathrm{AO}(0 \mathrm{ka}))$, while the AOVGCM and AOGCM experiments for $6 \mathrm{ka}$ climate share the same control experiment $(\mathrm{AOV}(0 \mathrm{ka}))$. Therefore, the difference between $(\mathrm{AO}(6 \mathrm{ka})-\mathrm{AO}(0 \mathrm{ka}))$ and $(\mathrm{A}(6 \mathrm{ka})-\mathrm{A}(0 \mathrm{ka}))$ allows us to clearly discuss the role of ocean feedback, and the difference between $(\mathrm{AOV}(6 \mathrm{ka})-\mathrm{AOV}(0 \mathrm{ka}))$ and $(\mathrm{AO}(6 \mathrm{ka})-$ $\mathrm{AO}(0 \mathrm{ka}))$ allows us to discuss the role of vegetation feedback during the mid-Holocene.

To quantitatively examine the extent to which the results of this single model over East Asia match those of other models, we also compare the present simulations to all 35 available PMIP coupled model experiments at this stage, including 14 AOGCMs plus six AOVGCMs from PMIP2 and eight AOGCMs plus seven AOVGCMs from PMIP3. Detailed information about the above PMIP models and experimental designs are available online at http://pmip2.lsce.ipsl.fr/ and http://pmip3.lsce.ipsl.fr/.

\section{Mid-Holocene East Asian climate change}

Before discussing the effect of dynamic ocean and vegetation feedbacks (next section), here we first describe the large-scale climate changes between $6 \mathrm{ka}$ and $0 \mathrm{ka}$ over East Asia based on the fully coupled experiments $\mathrm{AOV}(6 \mathrm{ka})$ and $\operatorname{AOV}(0 \mathrm{ka})$. In our analysis we focus on surface air temperature at $2 \mathrm{~m}$ above ground level, precipitation, effective precipitation (precipitation minus evaporation), and the East Asian summer monsoon. East Asia refers to the region within $15^{\circ} \mathrm{N}-55^{\circ} \mathrm{N}$ and $70^{\circ} \mathrm{E}-140^{\circ} \mathrm{E}$, and China refers to the mainland of China.

\subsection{Surface air temperature}

Figure 1 shows the geographical distribution of annual and seasonal temperature changes over East Asia between $6 \mathrm{ka}$ and $0 \mathrm{ka}$. Under the framework of the PMIP experiments, the annual mean incoming insolation was reduced by $0.36 \mathrm{~W} \mathrm{~m}^{-2}$ averaged over China during the mid-Holocene relative to the present day according to the algorithm of Berger (1978). Accordingly, the East Asian region experienced an annual cooling ranging from $0 \mathrm{~K}$ to $1.5 \mathrm{~K}$ at $6 \mathrm{ka}$, apart from in the area north of $50^{\circ} \mathrm{N}$ (Fig. 1a). The decrease in annual temperature was less than $1 \mathrm{~K}$ over China, and the change was less obvious $(<0.2 \mathrm{~K})$ over Northeast China. Averaged over the whole country, annual temperature was reduced by $0.5 \mathrm{~K}$ at $6 \mathrm{ka}$ with respect to $0 \mathrm{ka}$.

According to the algorithm of Berger (1978), the regionally averaged insolation over China was reduced by $10.97 \mathrm{~W} \mathrm{~m}^{-2}$ in winter, $8.20 \mathrm{~W} \mathrm{~m}^{-2}$ in spring (March-May), and $3.62 \mathrm{~W} \mathrm{~m}^{-2}$ in autumn, but increased by $21.34 \mathrm{~W} \mathrm{~m}^{-2}$ in summer at $6 \mathrm{ka}$ with respect to $0 \mathrm{ka}$. Similar to the annual mean, seasonal temperature change closely followed the above insolation change over China at $6 \mathrm{ka}$ (Fig. 1b-e). Cooler (warmer) than $0 \mathrm{ka}$ temperature occurred over most of China in winter and spring (in summer), with mean changes of $-1.3 \mathrm{~K}$ and $-1.5 \mathrm{~K}(1.1 \mathrm{~K})$ over the country, respectively. In autumn, the mid-Holocene temperature change was overall less than those in the other seasons, with a weak cooling 
(a) Annual

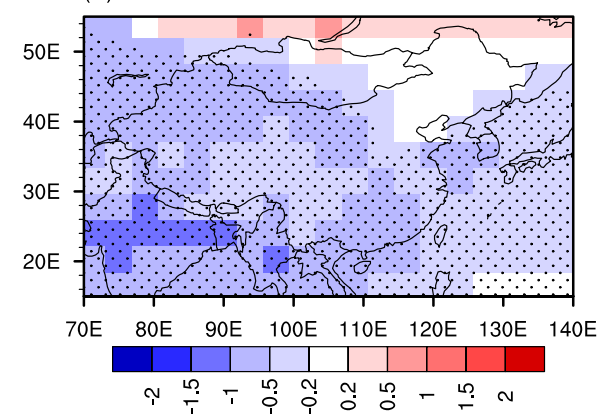

(b) Winter

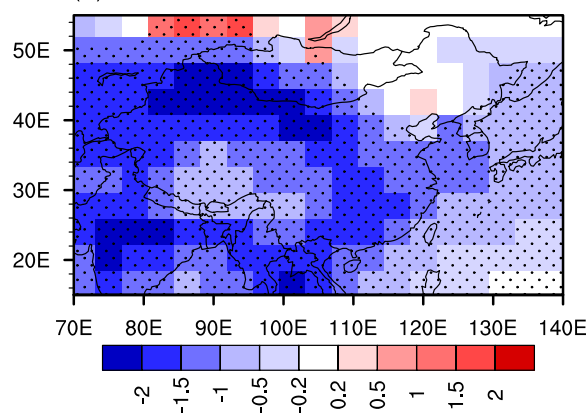

(d) Summer

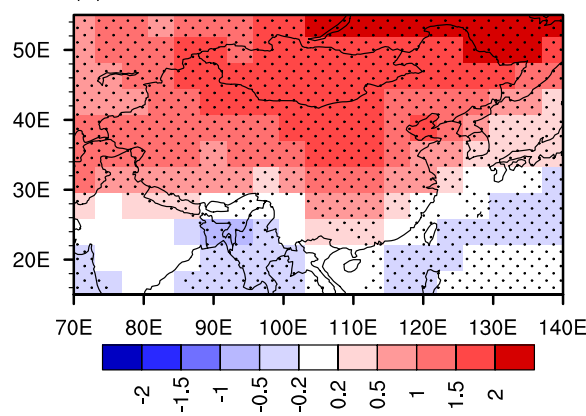

(c) Spring

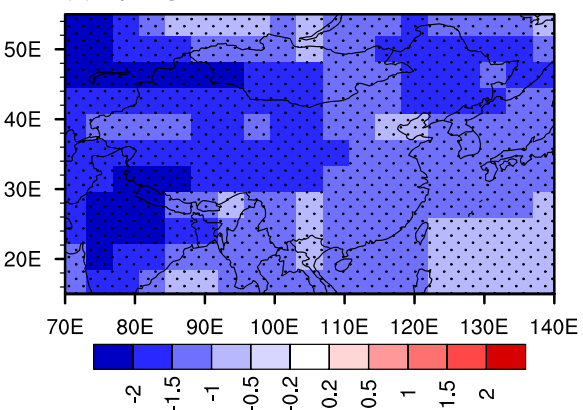

(e) Autumn

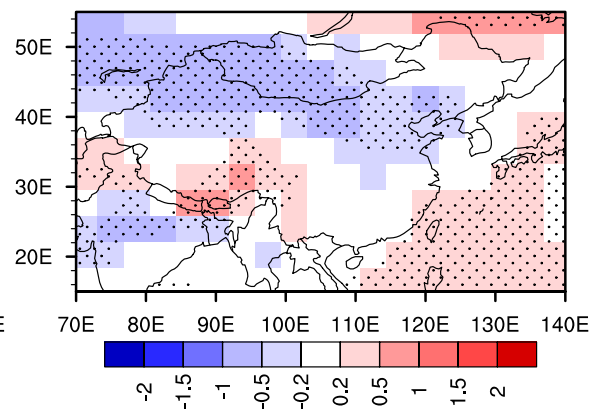

Fig. 1. Annual and seasonal temperature differences (units: K) between AOV(6 ka) and AOV(0 ka) experiments. The areas exceeding $90 \%$ confidence level are dotted.

of $0.1 \mathrm{~K}$ for the whole country. Note that these changes in annual and seasonal temperature fall within the range of the 13 PMIP AOVGCMs.

\subsection{Precipitation, evaporation, and effective precipitation}

With reference to $0 \mathrm{ka}$, the mid-Holocene annual precipitation increased by $0.1-0.5 \mathrm{~mm} \mathrm{day}^{-1}$ over the QinghaiTibetan Plateau, Inner Mongolia, Northeast China, and most of India, but reduced by $0.1-0.5 \mathrm{~mm} \mathrm{day}^{-1}$ over the middle and lower reaches of the Yangtze River valley and the East China Sea (Fig. 2a). Seasonally, the mid-Holocene precipitation reduced by $0.1-1.0 \mathrm{~mm} \mathrm{day}^{-1}$ and $0.1-1.5 \mathrm{~mm}_{\text {day }}{ }^{-1}$ in winter and spring, respectively, while it increased by $0.1-$ $1.0 \mathrm{~mm} \mathrm{day}^{-1}$ in autumn over most of China (Fig. 2b, c and e). The geographical distribution of summer precipitation change at $6 \mathrm{ka}$ was similar to that for the annual mean, but with a larger magnitude (Fig. 2d). Averaged over the country, changes in precipitation were $-1.7 \%$ for the annual mean, $-5.7 \%$ in winter, $-14.3 \%$ in spring, $7.4 \%$ in summer, and $5.9 \%$ in autumn at $6 \mathrm{ka}$ with reference to $0 \mathrm{ka}$.

The change of evaporation was about 2-3 times smaller than that of precipitation over East Asia during the midHolocene. The annual evaporation slightly increased by $0.02-0.20 \mathrm{~mm} \mathrm{day}^{-1}$ over most of China and northern India. Similar to but less in magnitude than the seasonal precipitation change over China, evaporation was generally decreased in winter and spring. Evaporation increased by $0.02-$ $0.50 \mathrm{~mm} \mathrm{day}^{-1}$ in summer, while its change was less than $0.1 \mathrm{~mm} \mathrm{day}^{-1}$ in autumn over the country.

Over the whole East Asia, the mid-Holocene changes in annual and seasonal effective precipitation were similar to those of precipitation both in spatial pattern and magnitude. 
(a) Annual

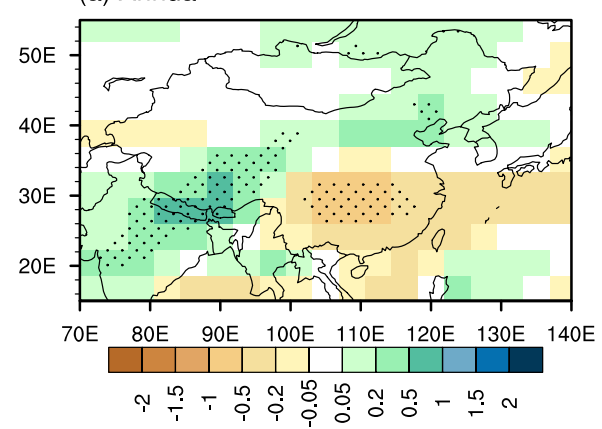

(b) Winter

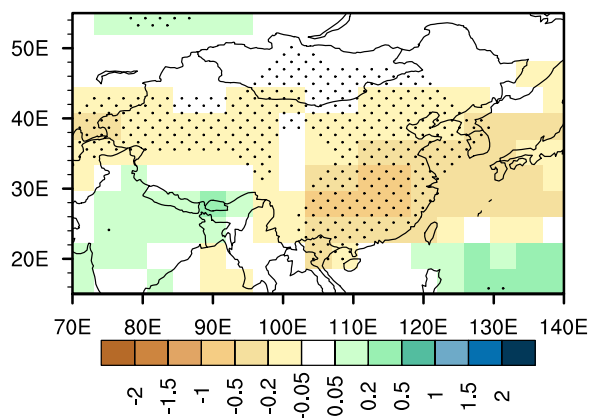

(d) Summer

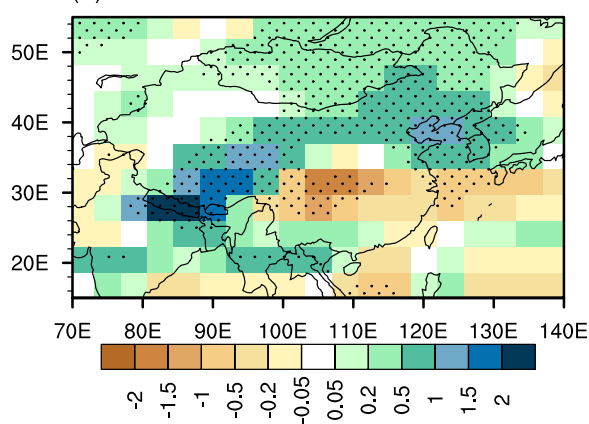

(c) Spring

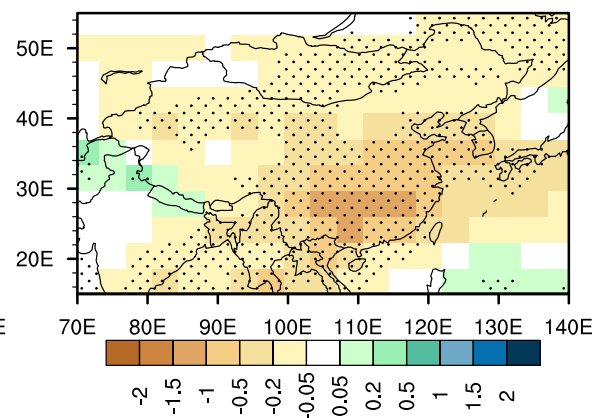

(e) Autumn

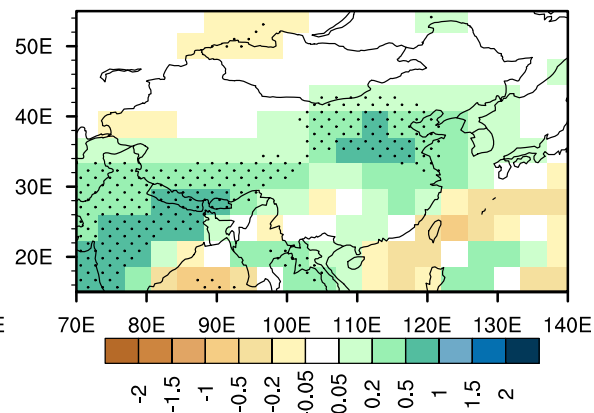

Fig. 2. Same as Fig. 1, but for precipitation changes (units: $\mathrm{mm}_{\mathrm{day}}{ }^{-1}$ ).

Furthermore, the annual precipitation and effective precipitation changes were generally dominated by the summer results, owing to summer precipitation accounting for more than half of the total annual precipitation over China, for example, $55 \%$ based on gauge observations for the period 1960-2009 (Sui et al., 2013). Comparatively, all of the above changes in annual and seasonal precipitation and effective precipitation are within the range of the PMIP models as discussed by Jiang et al. (2013a).

\subsection{East Asian summer monsoon (EASM)}

In response to an enhanced land-sea thermal contrast (Fig. 1d), and hence sea level pressure gradient, between the East Asian continent and adjacent oceans as a result of orbital forcing during the mid-Holocene summer, obvious southwesterly wind anomalies appeared over South and East China and stretched northward to Japan and the Korean
Peninsula, indicating a significantly stronger EASM at $6 \mathrm{ka}$ than at $0 \mathrm{ka}$ (Fig. 3). These changes are in line with the results of the 28 PMIP climate models with a demonstrable ability to simulate the modern EASM climatology (Jiang et al., 2013b). Accordingly, the southerly wind anomalies brought more water vapor from the South China Sea into the continent of East Asia, leading to an increased summer precipitation over southern China, North China, Northeast China, the Korean Peninsula, and Japan. Meanwhile, the easterly wind anomalies originated from the southern branch of the anomalous anticyclone over the Okhotsk Sea further provided more water vapor from the western North Pacific to Northeast China, contributing to increased summer precipitation over that region. Of note is that, different from the pattern as obtained from part of the PMIP2 models (Wang et al., 2010), the CCSM4 simulated precipitation was reduced over the middle and lower reaches of the Yangtze River valley 


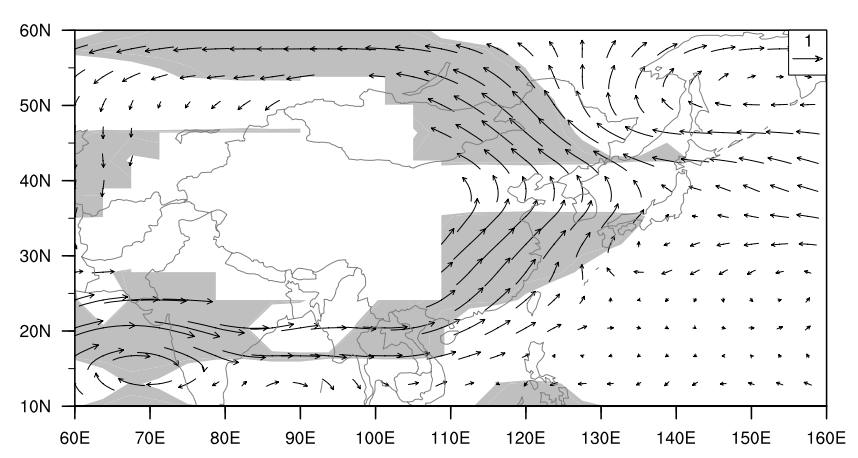

Fig. 3. Mid-Holocene-baseline anomalies of summer wind field at $850 \mathrm{hPa}$ (units: $\left.\mathrm{m} \mathrm{s}^{-1}\right)$ between $\mathrm{AOV}(6 \mathrm{ka})$ and $\mathrm{AOV}(0 \mathrm{ka})$ experiments. Regions with an elevation above $1500 \mathrm{~m}$ are left blank, and areas exceeding $90 \%$ confidence level are shaded.

during the mid-Holocene summer. This is because the subtropical high over the western North Pacific controls this region when the EASM circulation is stronger than normal, and hence less rainfall occurs over there and more rainfall over the southern (i.e., southern China) and northern (i.e., North China and Northeast China) sides of the western North Pacific subtropical high (Ding, 1994).

\section{Mid-Holocene ocean and vegetation feedbacks over East Asia}

To quantify the role of ocean and vegetation feedbacks, it is necessary to first describe the direct response of the atmosphere to the orbital forcing. Based on the difference between $\mathrm{A}(6 \mathrm{ka})$ and $\mathrm{A}(0 \mathrm{ka})$ experiments, the mid-Holocene temperature changes agreed in sign with the orbital-induced insolation change over China, with a mean cooling of $0.5 \mathrm{~K}$ for the annual mean, $1.8 \mathrm{~K}$ in winter, $1.0 \mathrm{~K}$ in spring, and $0.7 \mathrm{~K}$ in autumn, but a warming of $1.3 \mathrm{~K}$ in summer. Averaged over the country, precipitation increased by $0.09 \mathrm{~mm} \mathrm{day}^{-1}$ for the annual mean, $0.56 \mathrm{~mm} \mathrm{day}^{-1}$ in summer, and $0.06 \mathrm{~mm}_{\text {day }}{ }^{-1}$ in autumn, but reduced by $0.17 \mathrm{~mm} \mathrm{day}^{-1}$ in winter and $0.09 \mathrm{~mm} \mathrm{day}^{-1}$ in spring during the mid-Holocene. All of the above changes in temperature and precipitation fall within the results of the PMIP1 AGCMs with a good ability to simulate the modern climatology over China (Jiang et al., 2012, 2013a).

\subsection{Dynamic ocean feedback}

\subsubsection{Surface air temperature}

Owing to the large thermal inertia of the ocean, changes in SSTs lag changes in insolation by about 1-2 months (e.g., Marzin and Braconnot, 2009). Accordingly, the midHolocene SSTs were generally colder in the western North Pacific, the South China Sea, and the northern Indian Ocean for the annual mean and for the winter, spring, and summer seasons, while the opposite held true for autumn at the large scale (Fig. 4), in line with the pattern and magnitude obtained from the ensemble mean of the 10 PMIP3 models with SST data available (figures not shown). Figure 5 shows the midHolocene annual and seasonal temperature changes due to ocean feedback. Annual temperature was increased by $0.2-$ $0.5 \mathrm{~K}$ over most of China excluding Northeast China, northern Xinjiang, and the Qinghai-Tibetan Plateau, but was reduced over many of the other regions of East Asia (Fig. 5a). Of note is that those changes were not significant at the $90 \%$ confidence level. Averaged over China, ocean feedback induced an annual warming of $0.2 \mathrm{~K}$, which was close to the ocean-induced warming of $0.3 \mathrm{~K}$ as estimated from the PMIP models with and without dynamic ocean (Jiang et al., 2012). As such, the effect of ocean feedback on the annual temperature counteracted the direct response of the atmosphere to the orbital forcing over China during the mid-Holocene.

On the seasonal scale, SSTs generally increased in the high northern latitudes but reduced in the northern Indian Ocean, South China Sea, and the western North Pacific during the mid-Holocene winter (Fig. 4b). As a result, compared to the results of atmosphere-only models, winter meridional temperature gradient decreased through the low to high latitudes over and around the East Asian continent at the large scale, and in turn prevailing northwesterly winds that bring cold air from the high northern latitudes generally weakened over China in the lower troposphere (namely anomalous southerly winds shown in Fig. 6b). In this way, winter temperature rose over most of China (Fig. 5b). Previously, Jiang et al. (2012) argued that colder SSTs in the oceans adjacent to the East Asian continent favored a temperature decrease over China through their influence on surface heat exchange between land and the oceans. However, they neglected the fact that offshore winds prevailed in the lower troposphere and hence the transport of heat from those oceans to the mainland of China was quite limited during cold months. In autumn, higher SSTs occurred almost in all ocean areas of concern (Fig. 4e), particularly in the oceans north of Eurasia and adjacent to the East Asian continent. As a result, a largescale significant warming appeared in almost the whole East Asia (Fig. 5e). Over China, winter and autumn temperature increased on average by $0.5 \mathrm{~K}$ and $1.0 \mathrm{~K}$ due to ocean feedback, displaying comparable changes of $0.5 \mathrm{~K}$ and $0.7 \mathrm{~K}$ as estimated from the two kinds of the PMIP models with and without dynamic ocean (Jiang et al., 2012).

During the mid-Holocene spring, the colder SSTs in the western North Pacific and the South China Sea as well as the northern Indian Ocean (Fig. 4c) exerted a cooling effect of 0.2-1.5 K over East Asia excluding Southwest China (Fig. 5c), and hence ocean feedback amplified the direct effect of the orbital forcing. In summer, SSTs were warmer in the East China Sea, the Japan Sea, the western North Pacific north of $45^{\circ} \mathrm{N}$, and the ocean adjacent to southern India, but colder in other ocean areas of the low and middle northern latitudes (Fig. 4d). Accordingly, summer temperature 


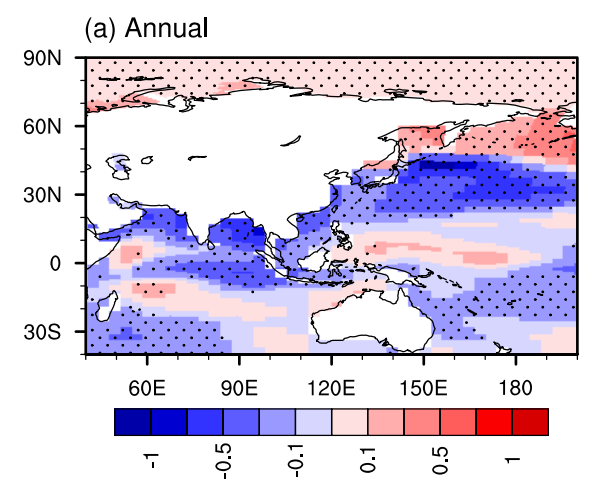

(b) Winter

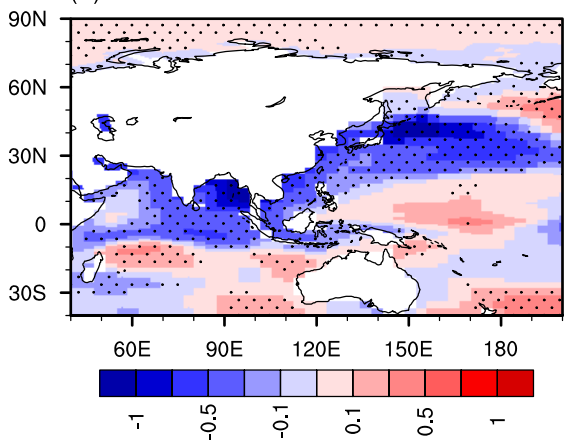

(d) Summer

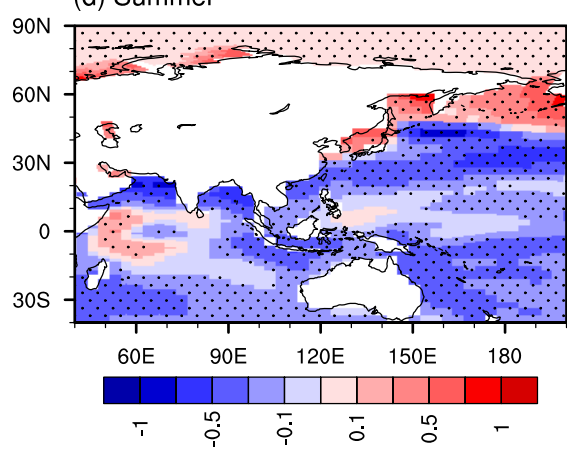

(c) Spring

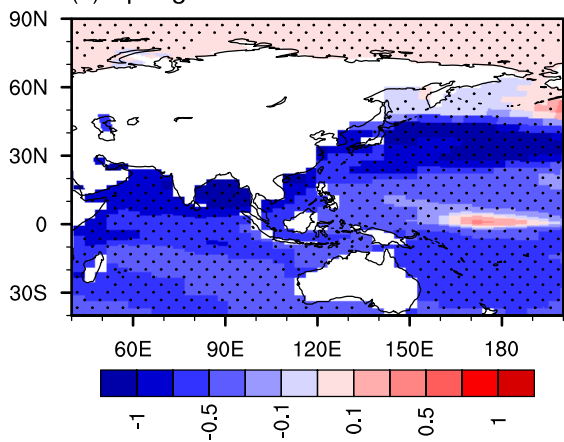

(e) Autumn

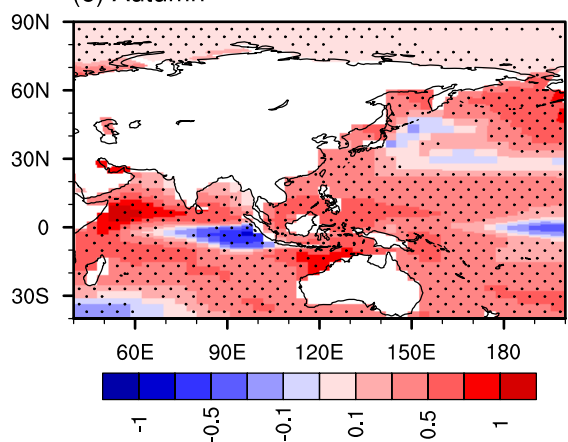

Fig. 4. Simulated differences in annual and seasonal sea surface temperatures (units: K) between AO(6 ka) and AO(0 ka) experiments. The areas exceeding $90 \%$ confidence level are dotted.

increased by $0.2-0.5 \mathrm{~K}$ over the Japan Sea, the Korean Peninsula, the mid-latitude regions of China approximately within $34^{\circ} \mathrm{N}$ and $44^{\circ} \mathrm{N}$, and eastern India, but decreased by $0.2-$ $0.5 \mathrm{~K}$ over other regions of East Asia (Fig. 5d). Over China, spring and summer temperature varied on average by $-0.6 \mathrm{~K}$ and $0.0003 \mathrm{~K}$. Both values were somewhat different from the corresponding $0.03 \mathrm{~K}$ and $-0.1 \mathrm{~K}$ as estimated from two kinds of the PMIP models with and without dynamic ocean (Jiang et al., 2012), implying a degree of uncertainty about ocean effect in these two seasons. Taken together, in comparison with the aforementioned orbitally induced seasonal temperature changes over China, the effect of ocean feedback on the seasonal temperature was negative in winter and autumn but positive in spring and summer during the midHolocene. Over the East Asian monsoon region, the CCSM4 simulated effect of ocean feedback was generally consistent in winter and spring, but inconsistent in summer and autumn, with the previous simulations of Dallmeyer et al. (2010) for that period.

\subsubsection{Precipitation}

The influence of the dynamic ocean on annual and seasonal precipitation is mainly through the changes in evaporation from the oceans and in large-scale atmospheric circulations. First, the mid-Holocene colder annual SSTs in the oceans adjacent to the East Asian continent (Fig. 4a) suppressed evaporation from the oceans, leading to a less amount of water vapor source for the whole East Asian continent. Second, ocean feedback gave rise to anomalous southwesterly winds 
(a) Annual

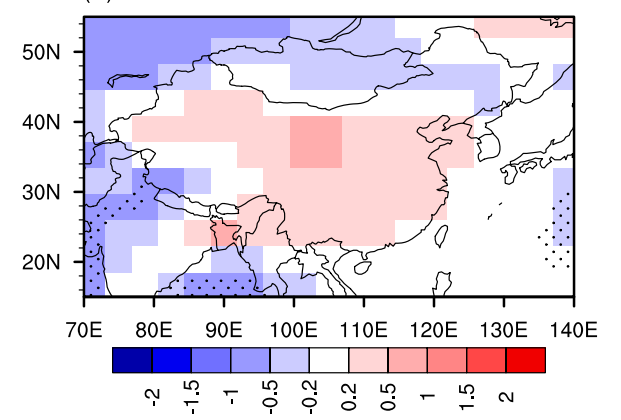

(b) Winter

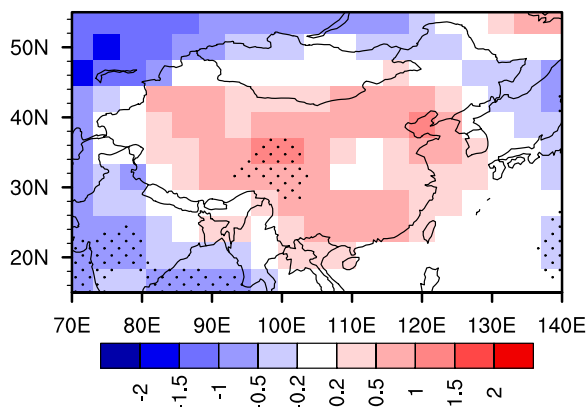

(d) Summer

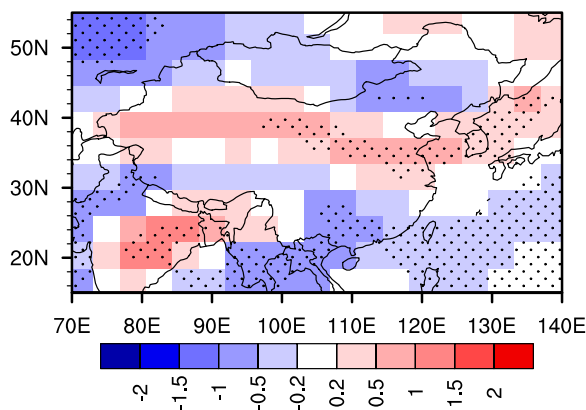

(c) Spring

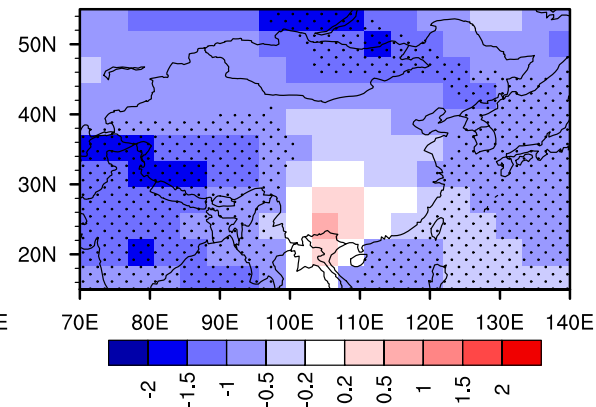

(e) Autumn

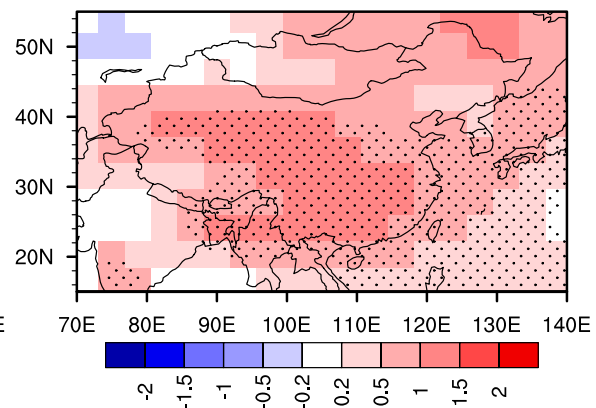

Fig. 5. Annual and seasonal temperature changes (units: $\mathrm{K})$ between $(\mathrm{AO}(6 \mathrm{ka})-\mathrm{AO}(0 \mathrm{ka}))$ and $(\mathrm{A}(6 \mathrm{ka})-\mathrm{A}(0 \mathrm{ka}))$ experiments. The areas exceeding $90 \%$ confidence level are dotted.

in eastern China for the annual mean (Fig. 6a). However, such an atmospheric circulation pattern was resulted from large-scale changes in winter, spring, and autumn (Fig. 6b, $\mathrm{c}$ and e). During the rainy season of summer, anomalous northerly or northwesterly winds prevailed over most parts of East Asia (Fig. 6d), and hence less onshore transport of water vapor from the marginal Seas of the East Asian continent. Accordingly, ocean feedback led to less annual precipitation over much of East Asia and the western North Pacific during the mid-Holocene (Fig. 7a). The annual mean precipitation decreased by an average of $0.14 \mathrm{~mm} \mathrm{day}^{-1}$ over China.

During the mid-Holocene winter, spring, and summer, colder SSTs in the northern Indian Ocean, the South China Sea, and the western North Pacific (Fig. 4b, c and d) decreased water vapor amount for the East Asian continent, particularly for the spring season. On the other hand, winter ocean feedback induced anomalous southerly winds in eastern China, namely a weakened monsoon circulation over East Asia, as a result of a weakened land-sea thermal contrast between the East Asian continent and adjacent oceans (Fig. 5b), which favored more water vapor transport from the northern Indian Ocean and the South China Sea to the mainland of China (Fig. 6b). Anomalous southwesterly or southerly winds favored the inland transport of water vapor from the northern Indian Ocean and the South China Sea during spring (Fig. 6c), and a weakened EASM circulation (Fig. 6d) suppressed summer rainfall, particularly in the middle and lower reaches of the Yangtze and Yellow River valleys where the strongest reduction reached $3.0 \mathrm{~mm}$ day $^{-1}$. During autumn, both warmer SSTs (Fig. 4e) and anomalous southwesterly winds in South China (Fig. 6e) were in favor of more precipitation over East Asia (Fig. 7e). Taken together, ocean feedback led to a change in seasonal precipitation of $0.04 \mathrm{~mm} \mathrm{day}^{-1}$ in winter, $-0.29 \mathrm{~mm} \mathrm{day}^{-1}$ in 


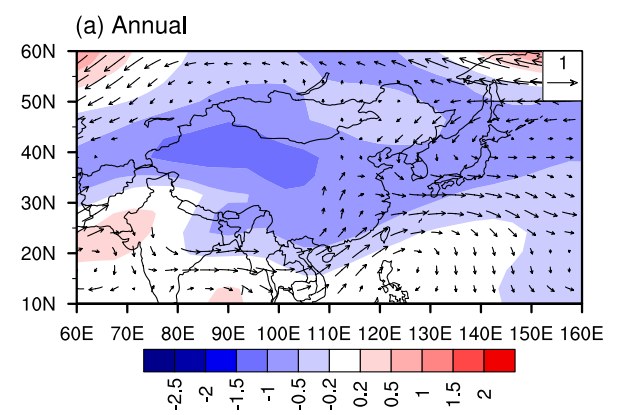

(b) Winter

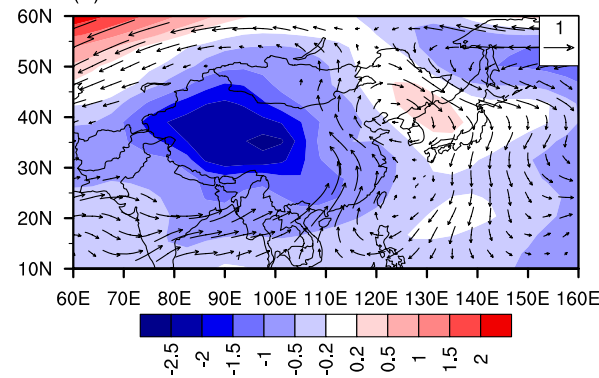

(d) Summer

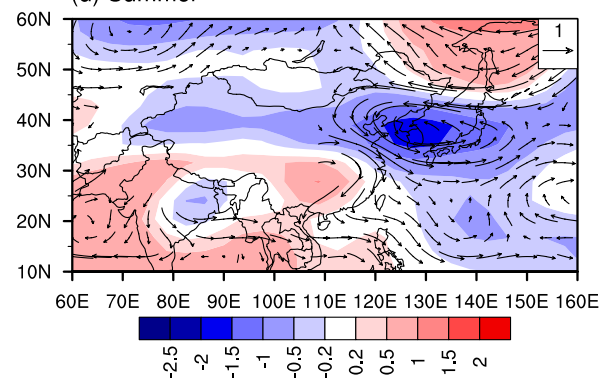

(c) Spring

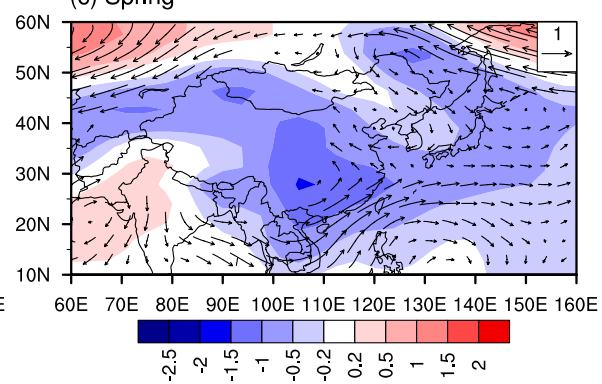

(e) Autumn

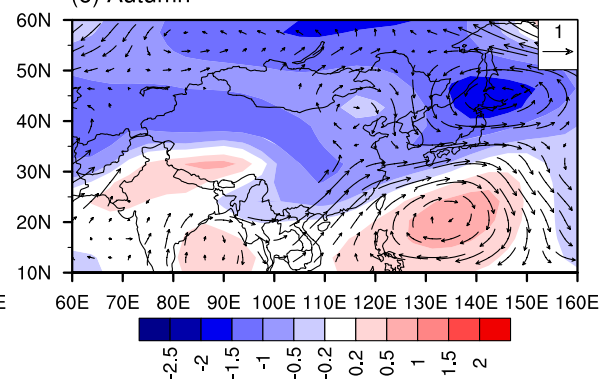

Fig. 6. Annual and seasonal sea level pressure (shaded, units: hPa) and $850 \mathrm{hPa}$ wind (vector, units: $\left.\mathrm{m} \mathrm{s}^{-1}\right)$ changes between (AO(6 ka)$\mathrm{AO}(0 \mathrm{ka}))$ and $(\mathrm{A}(6 \mathrm{ka})-\mathrm{A}(0 \mathrm{ka}))$ experiments. Wind fields with an elevation above $1500 \mathrm{~m}$ are left blank.

spring, $-0.34 \mathrm{~mm} \mathrm{day}^{-1}$ in summer, and $0.05 \mathrm{~mm} \mathrm{day}^{-1}$ in autumn over China. Comparatively, the CCSM4 simulated suppression of ocean feedback on the spring precipitation is consistent with that over the Yangtze and Huanghe plain within $31.54^{\circ} \mathrm{N}-38.97^{\circ} \mathrm{N}$ and $105^{\circ} \mathrm{E}-120^{\circ} \mathrm{E}$ as obtained by Dallmeyer et al. (2010). During summer, ocean feedbackinduced deficit in rainfall indicated a weakening of the East Asian summer monsoon rainfall. In general, such a negative effect agrees with most of the previous simulations of individual models (Liu et al., 2004; Ohgaito and Abe-Ouchi, 2007; Li and Harrison, 2008; Marzin and Braconnot, 2009; Dallmeyer et al., 2010), but differs from the results of either postive effect obtained from individual models (Braconnot et al., 2000; Wei and Wang, 2004) or little effect estimated from the two kinds of the PMIP models with and without dyanmic ocean (Zhao and Harrison, 2012; Jiang et al., 2013a).

\subsection{Dynamic vegetation feedback}

In the CLM4 component of CCSM4, there are 17 plant functional types (Gotangco Castillo et al., 2012). For brevity, here vegetation is assigned to four types, namely forest, shrub, grass, and desert, as expressed by the percent of land area within each model grid cell. In response to the mid-Holocene forcing, the CCSM4 simulated different vegetation conditions with respect to the pre-industrial period. Both the composition and distribution of vegetation were found to undergo changes over the East Asian continent. The changes in vegetation were characterized mainly by increases of forest at the expense of desert (Fig. 8). For example, forest replaced desert by more than $10 \%$ over most of Xinjiang and the central and western Qinghai-Tibetan Plateau, and forest replaced shrub and grass over much of Northeast China. Statistically, the nationwide change in the fraction of each kind of vegetation over China was $3.13 \%$ for forest, $0.49 \%$ for shrub, $-0.76 \%$ for grass, and $-2.86 \%$ for desert relative to the pre-industrial period.

\subsubsection{Surface air temperature}

On the annual scale, vegetation feedback led to a weak cooling in most parts of East Asia (Fig. 9a). Much of China 
(a) Annual

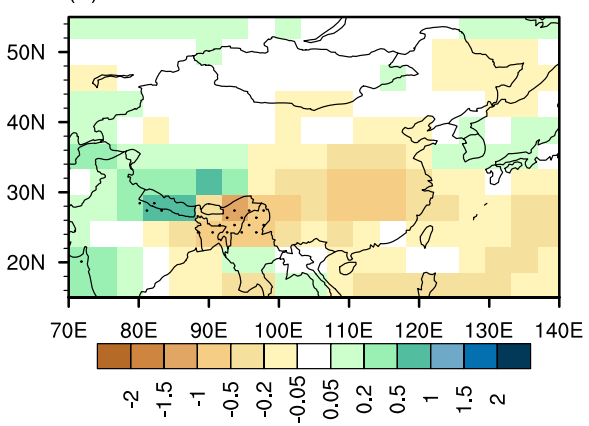

(b) Winter

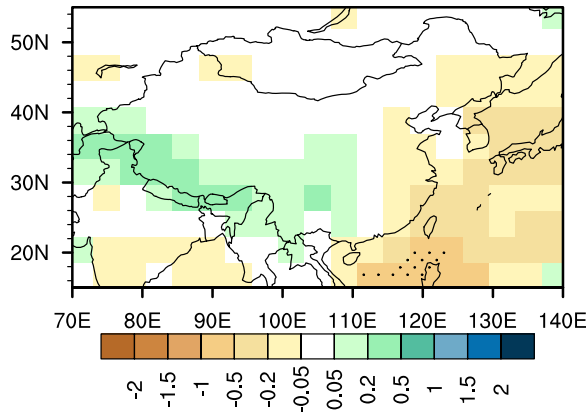

(d) Summer

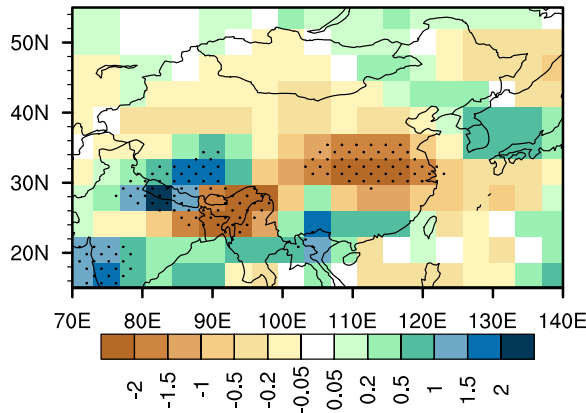

(c) Spring

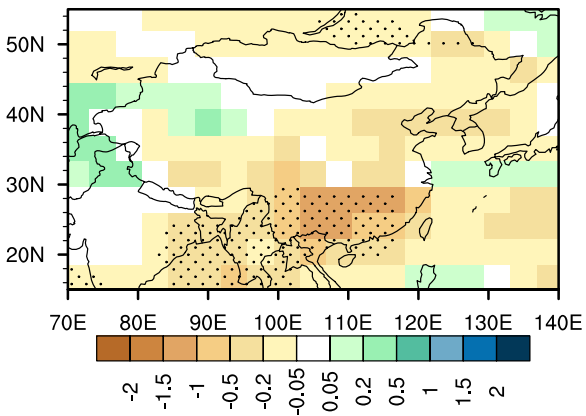

(e) Autumn

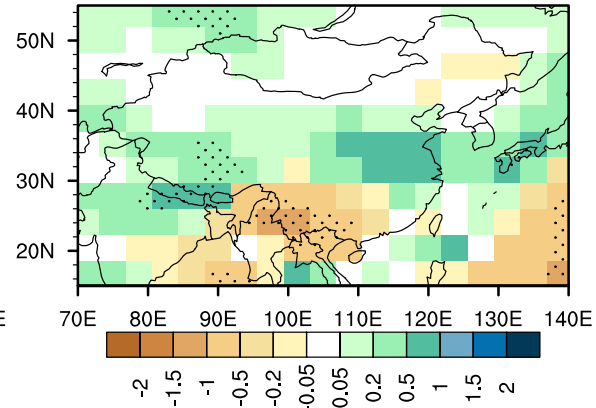

Fig. 7. Annual and seasonal precipitation changes (units: $\left.\mathrm{mm}_{\text {day }}{ }^{-1}\right)$ between $(\mathrm{AO}(6 \mathrm{ka})-\mathrm{AO}(0 \mathrm{ka}))$ and $(\mathrm{A}(6 \mathrm{ka})-\mathrm{A}(0 \mathrm{ka}))$ experiments. The areas exceeding $90 \%$ confidence level are dotted.

underwent a cooling of $0.1-0.5 \mathrm{~K}$, while part of northeastern and southwestern China and the southern Qinghai-Tibetan Plateau underwent a weak warming of $0.1-0.3 \mathrm{~K}$. Averaged over the country, the effect of dynamic vegetation induced an annual mean cooling of $0.2 \mathrm{~K}$, and hence vegetation feedback amplified the direct response of the annual mean temperature to the mid-Holocene orbital forcing over China. As is well known, vegetation change affects climate primarily through its effect on surface albedo, evaporation, transpiration, roughness length, and carbon stocks, and in turn surface heat exchange, atmospheric water vapor content and $\mathrm{CO}_{2}$ concentration, and so on (e.g., Sellers et al., 1996; Betts et al., 1997). It is found that surface albedo was generally increased in northern Northeast China, northern Xinjiang, and central China (Fig. 10a) where vegetation-induced cooling occurred (Fig. 9a), and this was because more solar radiation was reflected back into the sky. In central western China where the forest increased at the expanse of desert (Fig. 8), although surface albedo decreased throughout the year (Fig. 10a), annual temperature decreased (Fig. 9a) in response to increases of annual evapotranspiration and hence latent heat flux.

During the mid-Holocene winter, vegetation feedback exerted a warming effect of $0.1-1.0 \mathrm{~K}$ on temperature over Northeast China and the Qinghai-Tibetan Plateau but a comparable cooling effect over much of the rest of the country (Fig. 9b). The former two regions were covered by snow in winter, and the vegetation-induced warming was mostly derived from reduced surface albedo (Fig. 10b) due to the snow-masking effect of forest increase. During summer and autumn, vegetation feedback gave rise to additional cooling of $0.1-1.0 \mathrm{~K}$ over most of East Asia, particularly in its northern part (Fig. 9d and e). It was found that surface albedo was 
(a) forest $(3.13 \%)$

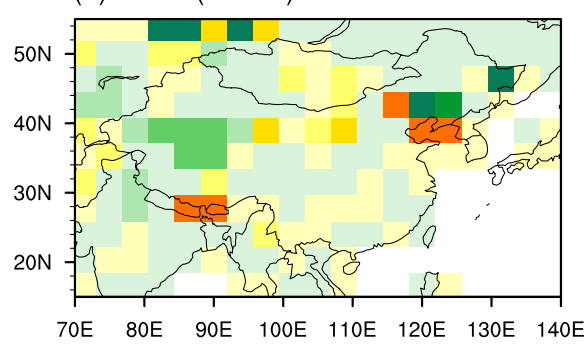

(c) grass $(-0.76 \%)$

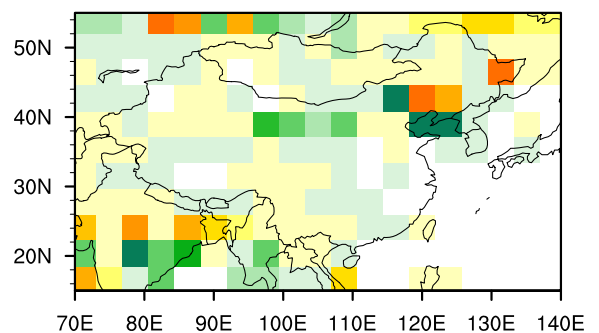

(b) shrub $(0.49 \%)$

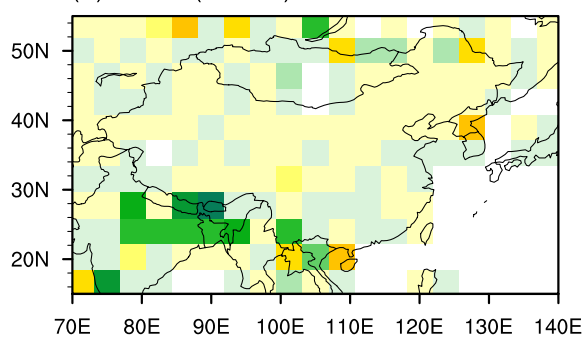

(d) desert (-2.86\%)

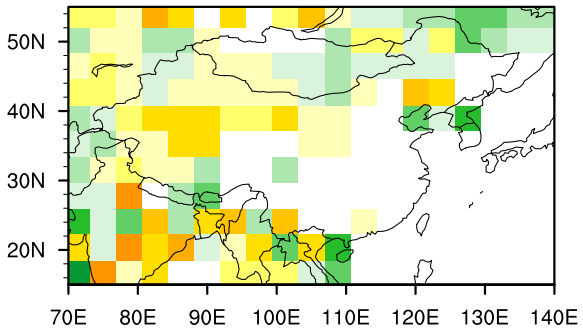

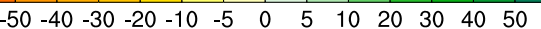

Fig. 8. Simulated vegetation changes, as expressed by the percent of land area within each model grid cell, between AOV(6 ka) and AOV(0 ka) experiments, with regionally averaged changes over China being given in parentheses.

generally increased in most of the cooling areas excluding the Qinghai-Tibetan Plateau in those two seasons (Fig. 10d and e), and total cloud amount was generally increased in much of northern East Asia in summer. Over South China and India, a vegetation-induced summer warming of $0.1-$ $0.3 \mathrm{~K}$ was resulted from a general reduction in surface albedo and total cloud amount. Averaged over China, vegetation feedback led to an additional cooling of $0.1 \mathrm{~K}$ in winter, $0.2 \mathrm{~K}$ in summer, and $0.4 \mathrm{~K}$ in autumn during the mid-Holocene. During spring, most parts of China underwent a weak warming of $0.1-0.5 \mathrm{~K}$ (Fig. 9c), with a regional average of $0.1 \mathrm{~K}$ over China. Such changes were related to changes in surface albedo (Fig. 10c), total cloud amount, and evapotranspiration over the country.

Model-model comparison indicates that the CCSM4 simulated vegetation feedback on the mid-Holocene seasonal temperature over China agrees with the estimation made from part of the PMIP2 models, such as the winter and autumn cooling effects in the FOAM models and the spring warming and summer cooling effects in the MRICGCM2.3.4fa models (Jiang et al., 2012). For spring, the present vegetation-induced warming is also observed over China in the ensemble mean of the six pairs of the PMIP2 models with and without dynamic vegetation (Jiang et al., 2012) and is also observed over the Yangtze and Huanghe plain as shown in Dallmeyer et al. (2010). By contrast, the warming effect of interactive vegetation on the QinghaiTibetan Plateau in autumn as estimated by the PMIP2 models (Jiang et al., 2012) and on the Yangtze and Huanghe plain in winter as simulated by Dallmeyer et al. (2010) is not seen in the present CCSM4 simulations. Such difference implies a level of uncertainty about the vegetation feedback on the East Asian annual and seasonal temperatures during the midHolocene.

\subsubsection{Precipitation}

The effect of dynamic vegetation feedback on the annual and seasonal precipitation was very weak during the midHolocene (Fig. 11). For the annual mean, precipitation decreased slightly over the southern Qinghai-Tibetan Plateau and southwestern China and increased slightly over the rest of China, with the changes of no more than $0.20 \mathrm{~mm} \mathrm{day}^{-1}$ (Fig. 11a). Averaged over the country, vegetation feedback induced a very weak decrease in annual precipitation by $0.002 \mathrm{~mm} \mathrm{day}^{-1}$ during the mid-Holocene.

On the seasonal scale, most parts of China experienced a small reduction of precipitation by $0.05-0.20 \mathrm{~mm} \mathrm{day}^{-1}$ in winter (Fig. 11b) and by $0.05-0.30 \mathrm{~mm} \mathrm{day}^{-1}$ in spring (Fig. 11c) during the mid-Holocene due to vegetation feedback. Conversely, precipitation increased slightly by $0.05-$ $0.20 \mathrm{~mm} \mathrm{day}^{-1}$ over the central Qinghai-Tibetan Plateau in winter and over Northeast and Southwest China in spring. In summer, precipitation decreased by $0.10-0.50 \mathrm{~mm}^{-1 a y}{ }^{-1}$ over much of the Qinghai-Tibetan Plateau and Southwest China, and it increased by $0.05-0.50 \mathrm{~mm} \mathrm{day}^{-1}$ over the rest of China (Fig. 11d). By contrast, autumn precipitation enhanced by $0.05-0.50 \mathrm{~mm} \mathrm{day}^{-1}$ over a large part of China, 
(a) Annual

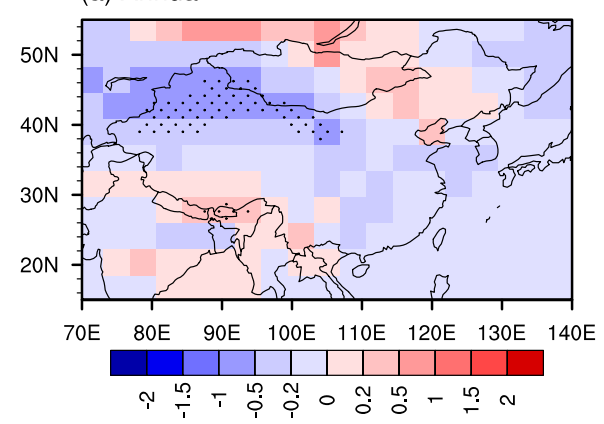

(b) Winter

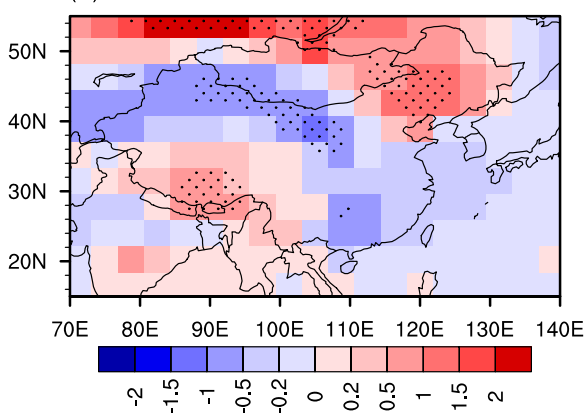

(d) Summer

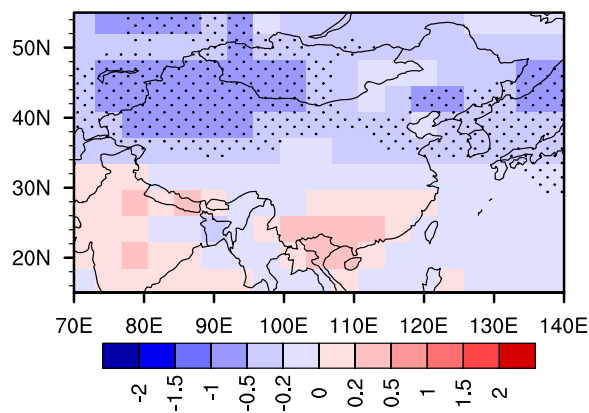

(c) Spring

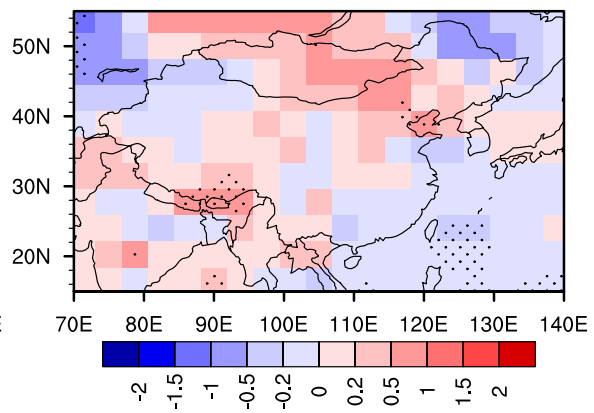

(e) Autumn

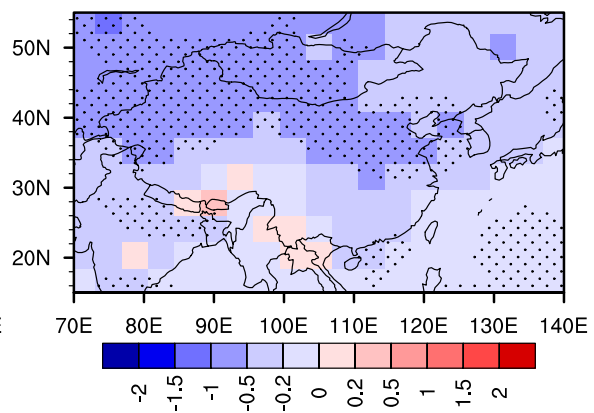

Fig. 9. Annual and seasonal temperature changes (units: K) between $(\mathrm{AOV}(6 \mathrm{ka})-\mathrm{AOV}(0 \mathrm{ka}))$ and $(\mathrm{AO}(6 \mathrm{ka})-\mathrm{AO}(0 \mathrm{ka}))$ experiments. The areas exceeding $90 \%$ confidence level are dotted.

apart from the northern part of Northeast China (Fig. 11e). Averaged over China, vegetation feedback led to a precipitation change of $-0.03 \mathrm{~mm} \mathrm{day}^{-1}$ in winter and spring, $-0.01 \mathrm{~mm} \mathrm{day}^{-1}$ in summer, and $0.06 \mathrm{~mm} \mathrm{day}^{-1}$ in autumn during the mid-Holocene.

Similarly, there are no robust vegetation feedbackinduced changes in seasonal precipitation over the East Asian monsoon region in the previous simulations of the ECHAM5/JSBACH-MPIOM model (Dallmeyer et al., 2010). Also noted is that most parts of India experienced an enhancement of precipitation by $0.10-0.40 \mathrm{~mm} \mathrm{day}^{-1}$ in autumn in our CCSM4 simulations (Fig. 11e), which was in accordance with their simulations (Dallmeyer et al., 2010).

\section{Model-data comparison}

Many efforts have been devoted to reconstructing the midHolocene climate over China by use of various proxy data. For temperature, here we choose the collected records of pollen, lake cores, paleosol, ice cores, peat, sediment, stalagmites, and fossil fruits at 64 sites across the country (see Fig. 3d in Jiang et al., 2012) for model-data comparison purposes. Those paleoenvironmental and paleoclimatic data indicate that warmer-than-present climate conditions prevailed over China during the mid-Holocene. More specifically, annual temperature elevation was approximately $1 \mathrm{~K}$ over southern China, approximately $2 \mathrm{~K}$ over the Yangtze River valley, $3 \mathrm{~K}$ over most of northern China, and $4-5 \mathrm{~K}$ on the Qinghai-Tibetan Plateau. As summarized in Jiang et al. (2012), proxy data also indicate warmer-than-present winter temperature (e.g., Shi et al., 1993; Yu et al., 1998, 2000; 
(a) Annual

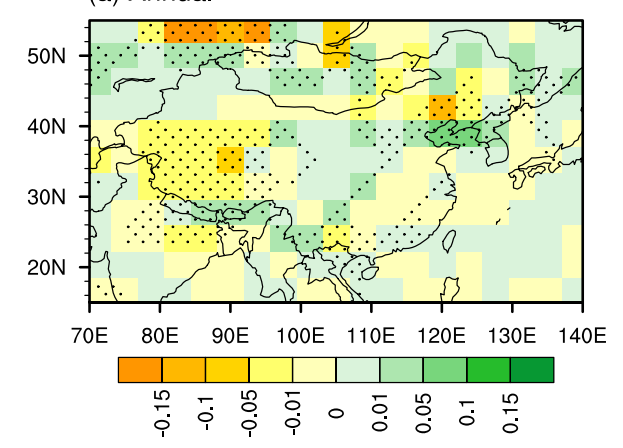

(b) Winter

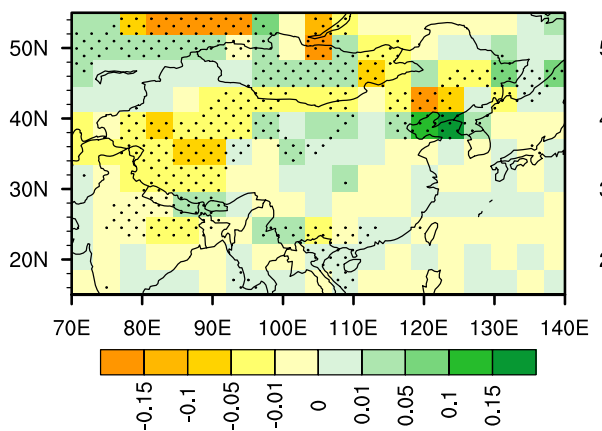

(d) Summer

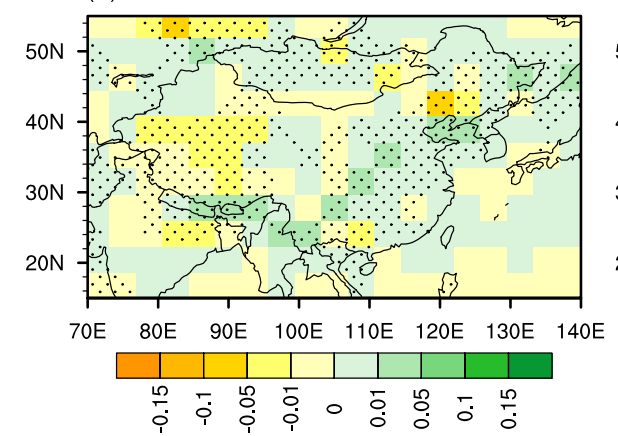

(c) Spring

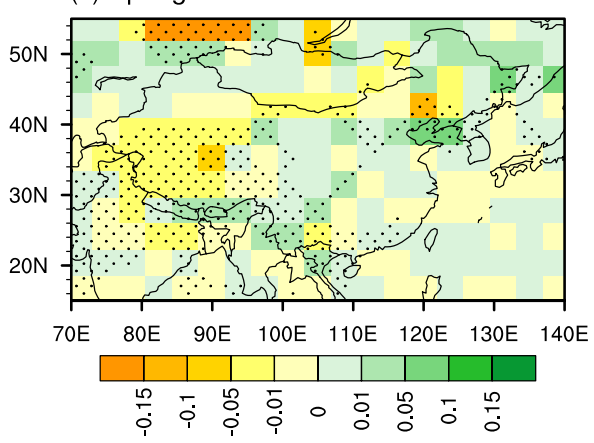

(e) Autumn

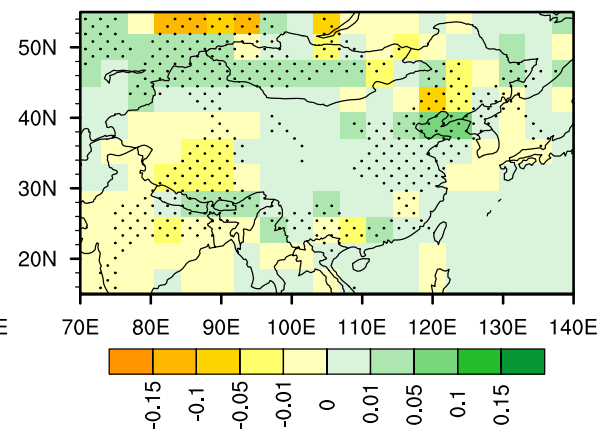

Fig. 10. Annual and seasonal surface albedo changes between $(\mathrm{AOV}(6 \mathrm{ka})-\mathrm{AOV}(0 \mathrm{ka}))$ and $(\mathrm{AO}(6 \mathrm{ka})-\mathrm{AO}(0 \mathrm{ka}))$ experiments. The areas exceeding $90 \%$ confidence level are dotted.

Ni et al., 2010), and a few studies further suggest that winter warming was stronger than the annual mean over China during the mid-Holocene (e.g., Xu et al., 1988; Kong et al., 1990, 1991; Shi et al., 1993; Tang et al., 2000; Guiot et al., 2008; Jiang et al., 2010; Wen et al., 2010).

Contrary to the above reconstructed annual and winter temperature warming, the present CCSM4 reproduced colder-than-pre-industrial annual and winter temperatures during the mid-Holocene over the country, except for Northeast China where temperature was slightly changed. On average, annual and winter temperatures reduced by $0.5 \mathrm{~K}$ and $1.3 \mathrm{~K}$ over China in the present CCSM 4 simulations. Note that such changes are in line with the results of both the 36 PMIP1 and PMIP2 models (Jiang et al., 2012) and the 10 PMIP3 models (Zheng et al., 2013), and hence add new model evidence to the mid-Holocene considerable model-data mismatch in annual and winter temperature changes over China. Based on the difference between the CCSM4 experiments of AOGCMs and AGCMs, ocean feedback led to increases of annual and winter temperatures by an average of $0.2 \mathrm{~K}$ and $0.5 \mathrm{~K}$ over China during the midHolocene, respectively, making the model results better agree with proxy records. By contrast, the CCSM4 simulated vegetation feedback amplified the mid-Holocene annual and winter temperature cooling, inducing an additional temperature reduction of $0.2 \mathrm{~K}$ and $0.1 \mathrm{~K}$ over China. Collectively, ocean feedback narrowed the model-data mismatch in annual and winter temperatures, whereas vegetation feedback pushed the model further away from proxy data over China during the mid-Holocene.

For the mid-Holocene annual precipitation or humidity changes, proxy records used here are composed of lake cores, 
(a) Annual

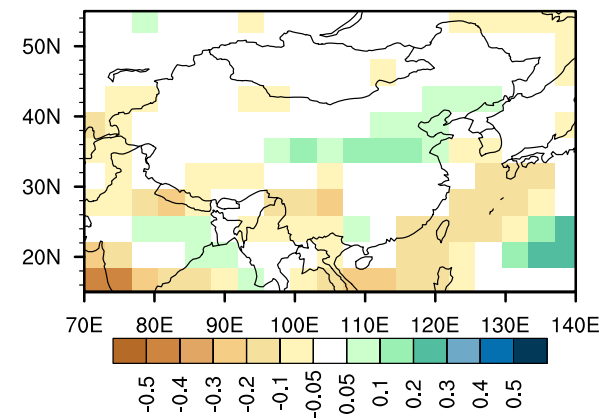

(b) Winter

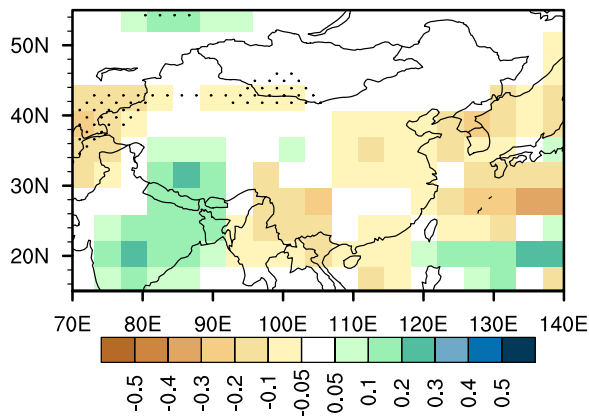

(d) Summer

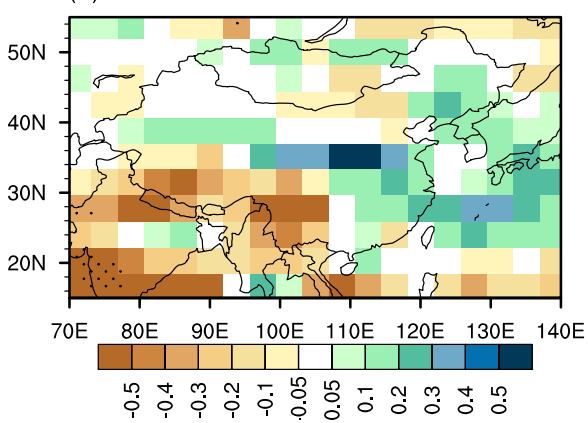

(c) Spring

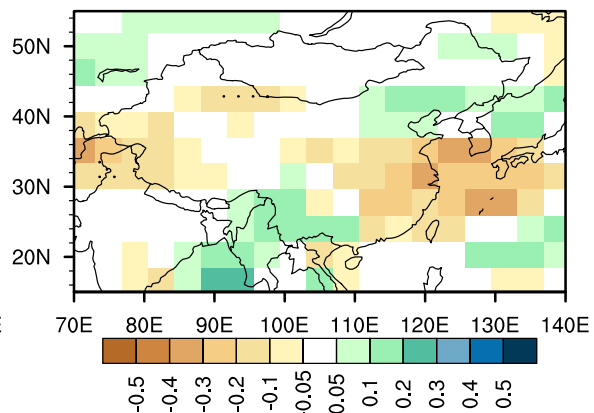

(e) Autumn

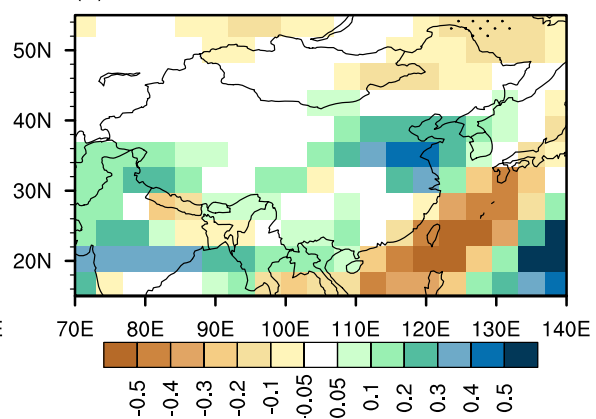

Fig. 11. Annual and seasonal precipitation changes (units: $\left.\mathrm{mm} \mathrm{day}^{-1}\right)$ between $(\mathrm{AOV}(6 \mathrm{ka})-\mathrm{AOV}(0 \mathrm{ka}))$ and $(\mathrm{AO}(6 \mathrm{ka})-\mathrm{AO}(0 \mathrm{ka}))$ experiments. The areas exceeding $90 \%$ confidence level are dotted.

ice cores, peat, stalagmites, and fluvial profiles at 24 sites across a large part of China (see Fig. 5b in Wang et al., 2010). It is shown that annual precipitation was greater than at present, being $70-80 \%$ higher over the Qinghai Lake area and $30 \%$ higher over Daihai Lake, Hidden Lake, and Ren Co Lake. Our model results are generally consistent with reconstructions over the latter three areas, but underestimate precipitation change over the Qinghai Lake area. In addition, the CCSM4 simulated precipitation reduction disagrees with several proxy records over central and South China (Wang et al., 2010; Jiang et al., 2013a). Proxy data are very sparse over Northeast China, preventing a model-data comparison at this stage. In general, the effect of ocean and vegetation feedbacks did not modify the above pattern in annual precipitation and effective precipitation changes, and hence contributed little to the model-data comparison in moisture conditions during the mid-Holocene.

\section{Summary and discussion}

In this study, the impact of interactive ocean and vegetation on the mid-Holocene climate change over East Asia are investigated by utilizing a new generation of the earth system model CCSM4. The strict experimental setup used here makes it more objective and straightforward to quantify dynamic ocean and vegetation feedbacks as compared to previous studies (e.g., Marzin and Braconnot, 2009; Jiang et al., 2012; Zhao and Harrison, 2012). Based on the fully coupled CCSM4 AOVGCM experiments, the mid-Holocene annual and seasonal temperature changes over China resulted mainly from the imposed orbital forcing and the reduction of atmospheric concentrations of greenhouse gases, and the simulated annual and winter cooling over China was contrary to the warming reconstructed from multiple proxy data. With reference to the pre-industrial period, the simulated 
mid-Holocene annual precipitation was greater over the Qinghai-Tibetan Plateau, Inner Mongolia, and Northeast China, but less over the middle and lower reaches of the Yangtze River valley, which was qualitatively consistent with the proxy records in the former regions but opposite to those in the latter regions. In response to an increase of $\sim 5 \%$ in the seasonal insolation in the Northern Hemisphere (Berger, 1978), southerly wind anomalies prevailed in the lower troposphere over eastern China and the western branch of the western North Pacific subtropical high during the midHolocene summer, and such an intensified EASM compares favorably with previous experiments of individual AOGCMs (e.g., Chen et al., 2002; Marzin and Braconnot, 2009; Zhou and Zhao, 2009; Liu et al., 2010; Bosmans et al., 2012) and the PMIP models (Wang et al., 2010; Zhao and Harrison, 2012; Jiang et al., 2013b; Zheng et al., 2013). It is suggested that an enhanced land-sea thermal contrast, and hence sea level pressure gradient, between the East Asian continent and the adjacent oceans was responsible for the EASM strengthening during the mid-Holocene. Overall, the CCSM4 simulated large-scale characteristics of the mid-Holocene East Asian climate change agree in many respects with previous studies (e.g., Braconnot et al., 2007; Dallmeyer et al., 2010; Jiang et al., 2012).

The dynamic ocean and vegetation feedbacks can modify the direct response of the surface climate to the midHolocene orbital forcing over East Asia. As a whole, ocean feedback-induced warming resulted from warmer (colder) SSTs in the high (low) northern latitudes made the midHolocene annual and winter temperatures much closer to proxy data than those in the atmosphere-only model over China, as was the case estimated from the PMIP models (Jiang et al., 2012). During the mid-Holocene summer, ocean feedback suppressed the East Asian monsoon rainfall, a negative feedback effect that agrees with most of the previous experiments of individual models (Liu et al., 2004; Ohgaito and Abe-Ouchi, 2007; Li and Harrison, 2008; Marzin and Braconnot, 2009; Dallmeyer et al., 2010), but differs from the results of either postive effect obtained from individual models (Braconnot et al., 2000; Wei and Wang, 2004) or little effect estimated from the PMIP models (Zhao and Harrison, 2012; Jiang et al., 2013a). Comparatively, the effect of dynamic vegetation on the mid-Holocene annual temperature is weak, with a regional average of $-0.2 \mathrm{~K}$ over China, while robust annual precipitation changes cannot be detected over East Asia. Based on the six pairs of the PMIP2 models with and without dynamic vegetation, Jiang et al. (2012) showed a large degree of uncertainty about the effect of interactive vegetation on the mid-Holocene annual temperature over China. The present CCSM4 simulations add more uncertainty to this issue, as done by the previous simulations of the ECHAM5/JSBACH-MPIOM model (Dallmeyer et al., 2010). To what extent, and how, the vegetation feedback affects the mid-Holocene East Asian monsoon climate calls for further investigations.
Finally, it remains unclear whether the mid-Holocene model-data mismatch in annual and winter temperatures and annual precipitation over China arises from the model, the proxy data, or both. It can be seen from our analysis, as well as previous studies (Dallmeyer et al., 2010; Jiang et al., 2012), that the dynamic ocean brings the simulated and reconstructed annual and winter temperatures much closer over China, but model-data disagreement still cannot be reconciled. On the other hand, our CCSM4 experiments and previous few studies imply a large degree of uncertainty, both in sign and magnitude, about the effect of dynamic vegetation on the East Asian climate. More simulations and reconstructions are required to quantify the ocean and vegeation feedbacks over East Asia and to disentangle the model-data mismatch over China during the mid-Holocene.

Acknowledgements. We sincerely thank the three anonymous reviewers for their helpful comments and suggestions on the earlier version of the manuscript. We acknowledge the National Center for Atmospheric Research (NCAR) for providing the CCSM4 model, the National Science Foundation (NSF) and the US Department of Energy (DOE) for sponsoring CCSM Project, and Joyce Bosmans, Pascale Braconnot, Johann Jungclaus, Akio Kitoh, Allegra N. LeGrande, Charline Marzin, Rumi Ohgaito, Bette L. Otto-Bliesner, Steven J Phipps, Leon Rotstayn, Stéphane Sénési, Tongwen $\mathrm{Wu}$, and Tianjun Zhou for providing information on the PMIP3 AOVGCMs and AOGCMs. Also, we acknowledge the international modeling groups for providing their data for analysis, and the Laboratoire des Sciences du Climat et de l'Environnement (LSCE) for collecting and archiving the PMIP model data. This research was supported by the Strategic Priority Research Program (XDA05120703 and XDB03020602) and the Knowledge Innovation Program (KZCX2-EW-QN202) of the Chinese Academy of Sciences and by the National Natural Science Foundation of China (41222034 and 41175072).

Edited by: G. Ramstein

\section{References}

Bartlein, P. J., Harrison, S. P., Brewer, S., Connor, S., Davis, B. A. S., Gajewski, K., Guiot, J., Harrison-Prentice, T. I., Henderson, A., Peyron, O., Prentice, I. C., Scholze, M., Seppä, H., Shuman, B., Sugita, S., Thompson, R. S., Viau, A. E., Williams, J., and Wu, H.: Pollen-based continental climate reconstructions at 6 and 21 ka: a global synthesis, Clim. Dynam., 37, 775-802, 2011.

Berger, A.: Long-term variations of daily insolation and Quaternary climatic changes, J. Atmos. Sci., 35, 2362-2367, 1978.

Betts, R. A., Cox, P. M., Lee, S. E., and Woodward, F. I.: Contrasting physiological and structural vegetation feedbacks in climate change simulations, Nature, 387, 796-799, 1997.

Bosmans, J. H. C., Drijfhout, S. S., Tuenter, E., Lourens, L. J., Hilgen, F. J., and Weber, S. L.: Monsoonal response to midholocene orbital forcing in a high resolution GCM, Clim. Past, 8, 723-740, doi:10.5194/cp-8-723-2012, 2012.

Braconnot, P., Joussaume, S., Marti, O., and Noblet, N. D.: Synergistic feedbacks from ocean and vegetation on the African mon- 
soon response to mid-Holocene insolation, Geophys. Res. Lett., 26, 2481-2484, 1999.

Braconnot, P., Marti, O., Joussaume, S., and Leclainche, Y.: Ocean feedback in response to $6 \mathrm{kyr}$ BP insolation, J. Climate, 13, 1537-1553, 2000.

Braconnot, P., Otto-Bliesner, B., Harrison, S., Joussaume, S., Peterchmitt, J.-Y., Abe-Ouchi, A., Crucifix, M., Driesschaert, E., Fichefet, Th., Hewitt, C. D., Kageyama, M., Kitoh, A., Laîné, A., Loutre, M.-F., Marti, O., Merkel, U., Ramstein, G., Valdes, P., Weber, S. L., Yu, Y., and Zhao, Y.: Results of PMIP2 coupled simulations of the Mid-Holocene and Last Glacial Maximum Part 1: experiments and large-scale features, Clim. Past, 3, 261277, doi:10.5194/cp-3-261-2007, 2007.

Chen, X., Yu, G., and Liu, J.: Mid-Holocene climate simulation and discussion on the mechanism of temperature changes in eastern Asia, Sci. China Ser. D, 32, 335-345, 2002 (in Chinese).

Dallmeyer, A., Claussen, M., and Otto, J.: Contribution of oceanic and vegetation feedbacks to Holocene climate change in monsoonal Asia, Clim. Past, 6, 195-218, doi:10.5194/cp-6-1952010, 2010.

Danabasoglu, G., Bates, S. C., Briegleb, B. P., Jayne, S. R., Jochum, M., Large, W. G., Peacock, S., and Yeager, S. G.: The CCSM4 ocean component, J. Climate, 25, 1361-1389, 2012.

Diffenbaugh, N. S. and Sloan, L. C.: Global climate sensitivity to land surface change: the Mid Holocene revisited, Geophys. Res. Lett., 29, 1476, doi:10.1029/2002GL014880, 2002.

Ding, Y. H.: Monsoons over China, Springer, 419 pp., 1994.

Gallimore, R., Jacob, R., and Kutzbach, J.: Coupled atmosphereocean-vegetation simulations for modern and mid-Holocene climates: Role of extratropical vegetation cover feedbacks, Clim. Dynam., 25, 755-776, 2005.

Ganopolski, A., Kubatzki, C., Claussen, M., Brovkin, V., and Petoukhov, V.: The influence of vegetation-atmosphere-ocean interaction on climate during the mid-Holocene, Science, 280, 1916-1919, 1998.

Gent, P. R., Danabasoglu, G., Donner, L. J., Holland, M. M., Hunke, E. C., Jayne, S. R., Lawrence, D. M., Neale, R. B., Rasch, P. J., Vertenstein, M., Worley, P. H., Yang, Z.-L., and Zhang, M.: The Community Climate System Model version 4, J. Climate, 24, 4973-4991, 2011.

Gotangco Castillo, C. K., Levis, S., and Thornton, P.: Evaluation of the new CNDV option of the Community Land Model: effects of dynamic vegetation and interactive nitrogen on CLM4 means and variability, J. Climate, 25, 3702-3714, 2012.

Guiot, J., Hai Bin Wu, Wen Ying Jiang, and Yun Li Luo: East Asian Monsoon and paleoclimatic data analysis: a vegetation point of view, Clim. Past, 4, 137-145, doi:10.5194/cp-4-137-2008, 2008.

Hewitt, C. D. and Mitchell, J. F. B.: A fully coupled GCM simulation of the climate of the mid-Holocene, Geophys. Res. Lett., 25, 361-364, 1998.

Holland, M. M., Bailey, D. A., Briegleb, B. P., Light, B., and Hunke, E.: Improved sea ice shortwave radiation physics in CCSM4: the impact of melt ponds and aerosols on Arctic sea ice, J. Climate, 25, 1413-1430, 2012.

Hunke, E. C. and Lipscomb, W. H.: CICE: The Los Alamos sea ice model, documentation and software, version 4.0, Los Alamos National Laboratory Tech. Rep. LA-CC-06-012, 76 pp., 2008.

Jansen, E., Overpeck, J., Briffa, K. R., Duplessy, J.-C., Joos, F., Masson-Delmotte, V., Olago, D., Otto-Bliesner, B., Peltier, W.
R., Rahmstorf, S., Ramesh, R., Raynaud, D., Rind, D., Solomina, O., Villalba, R., and Zhang, D.: Palaeoclimate, in: Climate Change 2007: The Physical Science Basis, edited by: Solomon S., Qin, D., Manning, M., Chen, Z., Marquis, M., Averyt, K. B., Tignor, M., and Miller, H. L., Cambridge University Press, 434 497, 2007.

Jiang, D., Lang, X., Tian, Z., and Wang, T.: Considerable modeldata mismatch in temperature over China during the midHolocene: results of PMIP simulations, J. Climate, 25, 41354153, 2012.

Jiang, D., Tian, Z., and Lang, X.: Mid-Holocene net precipitation changes over China: model-data comparison, Quaternary Sci. Rev., submitted, 2013a.

Jiang, D., Lang, X., Tian, Z., and Ju, L.: Mid-Holocene East Asian summer monsoon strengthening: insights from Paleoclimate Modeling Intercomparison Project (PMIP) simulations, Palaeogeogr. Palaeocl., 369, 422-429, 2013b.

Jiang, W., Guiot, J., Chu, G., Wu, H., Yuan, B., Hatté, C., and Guo, Z.: An improved methodology of the modern analogues technique for palaeoclimate reconstruction in arid and semi-arid regions, Boreas, 39, 145-153, 2010.

Joussaume, S. and Braconnot, P.: Sensitivity of paleoclimate simulation results to season definitions, J. Geophys. Res., 102, 19431956, 1997.

Joussaume, S., Taylor, K. E., Braconnot, P., Mitchell, J. F. B., Kutzbach, J. E., Harrison, S. P., Prentice, I. C., Broccoli, A. J., Abe-Ouchi, A., Bartlein, P. J., Bonfils, C., Dong, B., Guiot, J., Herterich, K., Hewitt, C. D., Jolly, D., Kim, J. W., Kislov, A., Kitoh, A., Loutre, M. F., Masson, V., McAvaney, B., McFarlane, N., Noblet, N. D., Peltier, W. R., Peterschmitt, J. Y., Pollard, D., Rind, D., Royer, J. F., Schlesinger, M. E., Syktus, J., Thompson, S., Valdes, P., Vettoretti, G., Webb, R. S., and Wyputta, U.: Monsoon changes for 6000 years ago: results of 18 simulations from the Paleoclimate Modeling Intercomparison Project (PMIP), Geophys. Res. Lett., 26, 859-862, 1999.

Kong, Z. C., Du, N. Q., Shan, F. S., Tong, G. B., Luo, S. J., and Fan, S. X.: Vegetational and climatic changes in the last 11,000 years in Qinghai Lake - numerical analysis based on palynology in core QH85-14C, Mar. Geol. Quaternary Geol., 10, 79-90, 1990 (in Chinese).

Kong, Z. C., Du, N. Q., Zhang, Y. J., Wang, F. B., Liang, Y. L., and Wang, X. C.: Discovery of Helicia fossil florule and sporo-pollen assemblage of Baohuashan in Jurong County and its climatic and botanic significance, Quaternary Sci., 11, 326-335, 1991 (in Chinese).

Kutzbach, J. E. and Liu, Z.: Response of the African monsoon to orbital forcing and ocean feedbacks in the middle Holocene, Science, 278, 440-443, 1997.

Kutzbach, J. E., Bonan, G., Foley, J., and Harrison, S. P.: Vegetation and soil feedbacks on the response of the African monsoon to orbital forcing in the early to middle Holocene, Nature, 384, 623 626, 1996.

Lawrence, D. M., Oleson, K. W., Flanner, M. G., Thornton, P. E., Swenson, S. C., Lawrence, P. J., Zeng, X., Yang, Z.-L., Levis, S., Sakaguchi, K., Bonan, G. B., and Slater, A. G.: Parameterization improvements and functional and structural advances in version 4 of the Community Land Model, J. Adv. Model. Earth Syst., 3, M03001, doi:10.1029/2011MS000045, 2011. 
Lawrence, D. M., Oleson, K. W., Flanner, M. G., Fletcher, C. G., Lawrence, P. J., Levis, S., Swenson, S. C., and Bonan, G. B.: The CCSM4 land simulation, 1850-2005: assessment of surface climate and new capabilities, J. Climate, 25, 2240-2260, 2012.

Levis, S., Bonan, G. B., and Bonfils, C.: Soil feedback drives the mid-Holocene North African monsoon northward in fully coupled CCSM2 simulations with a dynamic vegetation model, Clim. Dynam., 23, 791-802, 2004a.

Levis, S., Bonan, G. B., Vertenstein, M., and Oleson, K. W.: The Community Land Model's dynamic global vegetation model (CLM-DGVM): technical description and user's guide, NCAR Tech. Note NCAR/TN-459+IA, 50 pp., 2004 b.

Li, Y. F. and Harrison, S. P.: Simulations of the impact of orbital forcing and ocean on the Asian summer monsoon during the Holocene, Global Planet. Change, 60, 505-522, 2008.

Li, Y. F., Harrison, S. P., Zhao, P., and Ju, J. H.: Simulations of the impacts of dynamic vegetation on interannual and interdecadal variability of Asian summer monsoon with modern and midHolocene orbital forcings, Global Planet. Change, 66, 235-252, 2009

Liu, Y., He, J. H., Li, W. L., Chen, L. X., Li, W., and Zhang, B.: MM5 simulations of the China regional climate during the midHolocene, Acta Meteorol. Sin., 24, 468-483, 2010.

Liu, Z., Harrison, S. P., Kutzbach, J., and Otto-Bliesner, B.: Global monsoons in the mid-Holocene and oceanic feedback, Clim. Dynam., 22, 157-182, 2004.

Marzin, C. and Braconnot, P.: The role of the ocean feedback on Asian and African monsoon variations at $6 \mathrm{kyr}$ and $9.5 \mathrm{kyr} \mathrm{BP}$, C. R. Geosci., 341, 643-655, 2009.

Neale, R. B., Richter, J. H., Conley, A. J., Park, S., Lauritzen, P. H., Gettelman, A., Williamson, D. L., Rasch, P. J., Vavrus, S. J., Taylor, M. A., Collins, W. D., Zhang, M., and Lin, S.: Description of the NCAR Community Atmosphere Model (CAM 4.0), Tech. Rep. NCAR/TN-485+STR, National Center for Atmospheric Research, Boulder, CO, 194 pp., 2010.

Ni, J., Yu, G., Harrison, S. P., and Prentice, I. C.: Palaeovegetation in China during the late Quaternary: Biome reconstructions based on a global scheme of plant functional types, Palaeogeogr. Palaeocl., 289, 44-61, 2010.

O'ishi, R. and Abe-Ouchi, A.: Polar amplification in the mid-Holocene derived from dynamical vegetation change with a GCM, Geophys. Res. Lett., 38, L14702, doi:10.1029/2011GL048001, 2011.

Ohgaito, R. and Abe-Ouchi, A.: The role of ocean thermodynamics and dynamics in Asian summer monsoon changes during the mid-Holocene, Clim. Dynam., 29, 39-50, 2007.

Otto, J., Raddatz, T., and Claussen, M.: Climate variabilityinduced uncertainty in mid-Holocene atmosphere-oceanvegetation feedbacks, Geophys. Res. Lett., 36, L23710, doi:10.1029/2009GL041457, 2009a.

Otto, J., Raddatz, T., Claussen, M., Brovkin, V., and Gayler, V.: Separation of atmosphere-ocean-vegetation feedbacks and synergies for mid-Holocene climate, Geophys. Res. Lett., 36, L09701, doi:10.1029/2009GL037482, 2009b.

Prentice, I. C. and Webb III, T.: BIOME 6000: reconstructing global mid-Holocene vegetation patterns from palaeoecological records, J. Biogeogr., 25, 997-1005, 1998.

Sellers, P. J., Bounoua, L., Collatz, G. J., Randall, D. A., Dazlich, D. A., Los, S. O., Berry, J. A., Fung, I., Tucker, C. J., Field, C.
B., and Jensen, T. G.: Comparison of radiative and physiological effects of doubled atmospheric $\mathrm{CO}_{2}$ on climate, Science, 271, 1402-1406, 1996.

Shi, Y., Kong, Z., Wang, S., Tang, L., Wang, F., Yao, T., Zhao, X., Zhang, P., and Shi, S.: Mid-Holocene climates and environments in China, Global Planet. Change, 7, 219-233, 1993.

Shields, C. A., Bailey, D. A., Danabasoglu, G., Jochum, M., Kiehl, J. T., Levis, S., and Park, S.: The low-resolution CCSM4, J. Climate, 25, 3993-4014, 2012.

Smith, R., Jones, P., Briegleb, B., Bryan, F., Danabasoglu, G., Dennis, J., Dukowicz, J., Eden, C., Fox-Kemper, B., Gent, P., Hecht, M., Jayne, S., Jochum, M., Large, W., Lindsay, K., Maltrud, M., Norton, N., Peacock, S., Vertenstein, M., and Yeager, S.: The Parallel Ocean Program (POP) reference manual, ocean component of the Community Climate System Model (CCSM), Los Alamos National Laboratory Tech. Rep. LAUR-10-01853, 141pp., 2010.

Sui, Y., Jiang, D., and Tian, Z.: Latest update of the climatology and changes in the seasonal distribution of precipitation over China, Theor. Appl. Climatol., 113, 599-610, 2013.

Tang, L. Y., Shen, C. M., Liu, K., and Overpeck, J. T.: Changes in South Asian monsoon: New high-resolution paleoclimatic records from Tibet, China, Chinese Sci. Bull., 45, 87-91, 2000.

Texier, D., Noblet, N. D., and Braconnot, P.: Sensitivity of the African and Asian monsoons to mid-Holocene insolation and data-inferred surface changes, J. Climate, 13, 164-181, 2000.

Thornton, P. E., Lamarque, J.-F., Rosenbloom, N. A., and Mahowald, N. M.: Influence of carbon-nitrogen cycle coupling on land model response to $\mathrm{CO}_{2}$ fertilization and climate variability, Global Biogeochem. Cy., 21, GB4018, doi:10.1029/2006GB002868, 2007.

Tian, Z., Jiang, D., Zhang, R., and Sui, Y.: Long-term climate simulation of CCSM4.0 and evaluation of its performance over East Asia and China, Chinese J. Atmos. Sci., 36, 619-632, 2012 (in Chinese).

Timm, O., Timmermann, A., Abe-Ouchi, A., Saito, F., and Segawa, T.: On the definition of seasons in paleoclimate simulations with orbital forcing, Paleoceanography, 23, PA2221, doi:10.1029/2007PA001461, 2008.

Voss, R. and Mikolajewicz, U.: The climate of 6000 years BP in near-equilibrium simulations with a coupled AOGCM, Geophys. Res. Lett., 28, 2213-2216, 2001.

Wang, H. J.: Role of vegetation and soil in the Holocene megathermal climate over China, J. Geophys. Res., 104, 9361-9367, 1999.

Wang, H. J.: The seasonal climate and low frequency oscillation in the simulated mid-Holocene megathermal climate, Adv. Atmos. Sci., 17, 445-457, 2000.

Wang, H. J.: The mid-Holocene climate simulated by a grid-point AGCM coupled with a biome model, Adv. Atmos. Sci., 19, 205218, 2002.

Wang, T., Wang, H. J., and Jiang, D.: Mid-Holocene East Asian summer climate as simulated by the PMIP2 models, Palaeogeogr. Palaeocl., 288, 93-102, 2010.

Wang, T. and Wang, H. J.: Mid-Holocene Asian summer climate and its responses to cold ocean surface simulated in the PMIP2 OAGCMs experiments, J. Geophys. Res., 118, 41174128, doi:10.1002/jgrd.50287, 2013.

Wei, J. F. and Wang, H. J.: A possible role of solar radiation and ocean in the mid-Holocene East Asian monsoon climate, Adv. Atmos. Sci., 21, 1-12, 2004. 
Wen, R. L., Xiao, J. L., Chang, Z. G., Zhai, D. Y., Zhou, L., Xu, Q. H., Li, Y. C., and Itoh, S.: Holocene vegetation and climate changes reflected by the pollen record of Hulun Lake, north eastern Inner Mongolia, Quaternary Sci., 30, 1105-1115, 2010 (in Chinese).

Wohlfahrt, J., Harrison, S. P., and Braconnot, P.: Synergistic feedbacks between ocean and vegetation on mid- and high-latitude climates during the mid-Holocene, Clim. Dynam., 22, 223-238, 2004.

Xu, Q. H., Chen, S. Y., Kong, Z. C., and Du, N. Q.: Preliminary discussion of vegetation succession and climatic change since the Holocene in the Baiyangdian Lake district, Acta Phytoecol. Geobotan. Sin., 12, 143-151, 1988 (in Chinese).

Yu, G., Prentice, I. C., Harrison, S. P., and Sun, X.: Pollen-based biome reconstructions for China at 0 and 6000 years, J. Biogeogr., 25, 1055-1069, 1998.

Yu, G., Chen, X., Ni, J., Cheddadi, R., Guiot, J., Han, H., Harrison, S. P., Huang, C., Ke, M., Kong, Z., Li, S., Li, W., Liew, P., Liu, G., Liu, J., Liu, Q., Liu, K.-B., Prentice, I. C., Qui, W., Ren, G., Song, C., Sugita, S., Sun, X., Tang, L., Van Campo, E., Xia, Y., Xu, Q., Yan, S., Yang, X., Zhao, J., and Zheng, Z.: Palaeovegetation of China: a pollen data-based synthesis for the mid-Holocene and last glacial maximum, J. Biogeogr., 27, 635-664, 2000.
Zhao, Y. and Harrison, S. P.: Mid-Holocene monsoons: A multimodel analysis of the inter-hemispheric differences in the responses to orbital forcing and ocean feedbacks, Clim. Dynam., 39, 1457-1487, 2012.

Zheng, W. and Yu, Y.: The Asian monsoon system of the midHolocene simulated by a coupled GCM, Quaternary Sci., 29, 1135-1145, 2009 (in Chinese).

Zheng, W., Wu, B., He, J., and Yu, Y.: The East Asian Summer Monsoon at mid-Holocene: results from PMIP3 simulations, Clim. Past, 9, 453-466, doi:10.5194/cp-9-453-2013, 2013.

Zheng, Y. Q., Yu, G., Wang, S. M., Xue, B., Zhuo, D. Q., Zeng, X. M., and Liu, H. Q.: Simulation of paleoclimate over East Asia at $6 \mathrm{ka} \mathrm{BP}$ and $21 \mathrm{ka} \mathrm{BP}$ by a regional climate model, Clim. Dynam., 23, 513-529, 2004.

Zhou, B. and Zhao, P.: Inverse correlation between ancient winter and summer monsoons in East Asia? Chinese Sci. Bull., 54, 3760-3767, 2009. 